\title{
Does Country Risks Predict Stock Returns and Volatility? Evidence from a Nonparametric Approach
}

\author{
Tahir Suleman ${ }^{*}$, Rangan Gupta ${ }^{* *}$ and Mehmet Balcilar ${ }^{* * *}$
}

\begin{abstract}
We use the $k$-th order nonparametric causality test at monthly frequency over the period of 1984:1 to 2015:12 to analyze whether aggregate country risk, and its components (economic, financial and political) can predict movements in stock returns and volatility of eighty-three developed and developing economies. The nonparametric approach controls for the existing misspecification of a linear framework of causality, and hence, the weak evidence of causality obtained under the standard Granger tests cannot be relied upon. When we apply the nonparametric test, we find that, while there is no evidence of predictability of squared stock returns barring one case, at times, there are nearly 50 percent of the countries where the aggregate risks and its components tend to predict stock returns and realized volatility.
\end{abstract}

Keywords: Country risks, returns, volatility, nonparametric higher-order causality.

JEL Codes: C22, G10.

\section{Introduction}

Stock returns and its volatility, with the latter often associated with uncertainty, are among the most important indicators for practitioners in finance o one hand. This is because it helps them in capital budgeting and portfolio management decisions, which in turn, directly reflect companies' financial health and future prospects (Poon and Granger, 2003; Rapach et al., 2008; Bekiros et al., 2016a). For academics, on the other hand, predictability of financial market movements challenges the idea of market efficiency, and thus, assists in building realistic asset pricing models (Rapach and Zhou, 2013). Hence, predicting returns and volatility is of tremendous importance to both practitioners and academics alike. However, predicting financial market movements is highly challenging, since it inherently comprises of stochastic as well as

\footnotetext{
* Corresponding author. School of Economics and Finance, Victoria University of Wellington, New Zealand and School of Business, Wellington Institute of Technology, New Zealand. Email: tahir.suleman@,vuw.ac.nz.

** Department of Economics, University of Pretoria, Pretoria, 0002, South Africa; IPAG Business School, Paris, France. Email: rangan.gupta@up.ac.za.

*** Department of Economics, Eastern Mediterranean University, Famagusta, via Mersin 10, Northern Cyprus, Turkey and Department of Economics, University of Pretoria, Pretoria, 0002, South Africa; IPAG Business School, Paris, France. Email: mehmet@mbalcilar.net.
} 
nonlinear components (Bekiros et al., 2016b). Not surprisingly, a wide array of linear, nonlinear and nonparametric predictive models with variety of predictors related to domestic and international financial, macroeconomic, institutional, behavioural, and financial and economic uncertainty have been used (see Rapach and Zhou (2013) and Aye et al., (2015) for detailed literature reviews in this regard). The empirical evidence of predictability on returns and volatility is, however, mixed.

In the literature, we find a longstanding relationship between country risk and the financial markets. Risk rating agencies like Standard and Poor's, Moody's, Euromoney, Institutional Investor, Economist Intelligence Unit, and the ICRG analyze qualitative and quantitative information regarding alternative measures of political, economic and financial risk into associated composite risk ratings. These agencies provide ratings that reflect the risk inherent in a country and a reliable method of risk assessment. In the literature we find researchers (e.g., Erb, Harvey \& Viskanta (1995); Diamonte, Liew \& Stevens (1996); Bilson, Brailsford, and Hooper (2002; Hassan, Maroney, Monir El-Sady \& Telfah (2003); Suleman \& Daglish (2015)) used these ratings as a proxy of country risk e.g., ICRG and IICCR (Institutional Investor Country Credit Rating).

The relationship between country risk and stock market returns was initially examined by Erb, Harvey, and Viskanta (1995) using a country's credit rating from institutional investor's semiannual survey of bankers. Their results suggest that higher credit risk countries are associated with higher expected returns. They also validate that country credit ratings have considerable predictive power in discriminating between high expected returns and low expected returns countries. Erb, Harvey, and Viskanta (1996) investigated the four country risk components from International Country risk guide and one from Institutional Investors' rating. They examined the relationship between these ratings and future expected returns. They conclude that higher expected returns are associated with higher risk components.

Bilson et al. (2002) extended the political risk literature in two ways. First, they presented a model of return variation that incorporates political risk after taking into account both the global and local influence on returns. Second, they tested the impact of country risk at both individual and aggregated portfolio levels. They found that political risk is important in explaining return variation in the individual emerging markets, particularly in the Pacific Basin, but not in the developed markets. However, economic risk and financial risk are more important for developed markets as compare to political risk. Ramcharran (2003) extended this literature by using the data 
from European Credit Ratings to estimate the effect of political, economic and credit risk on equity returns, dividend yield, price-to-earnings ratio and price-to-book ratios from 21 emerging equity markets. For analysis purposes a panel model was used to estimate over a shorter period from 1992 to 1999 and concluded that these ratings has a significant impact on emerging market returns.

Hassan, et al. (2003) used the data from the ICRG of political risk services. They examined the effect of local factors by utilizing the country's political, financial and economic risk on the stock market volatility in the context of ten emerging markets in the Middle East and Africa (MEAF). They used the GARCH-M model by allowing the country's risk shocks in local factors to affect conditional variance. They found that the shocks in the political, economic and financial risk rating transfer the volatility constraints in the MEAF emerging markets. Further, only three out of ten markets significantly determine stock market volatility using political risk. However, five out of ten countries have only three years of data, which might raise questions on the findings.

Most recently Suleman and Randal (2016) proposes a framework for predicting market returns and volatility using changes in the country's political and composite risk. They identify the appropriate lag to calculate changes over, and how the changes should be included in mean and volatility equations. By analysing 47 emerging and 21 developed markets, they find predictive power primarily for volatility of emerging markets. Further, Cermeño and Suleman (2014) studied the link between country risk -measured by economic, financial, political as well as composite risk indexes- and volatility of stock market returns. They used a panel-GARCH model with both asymmetric and GARCH-in-mean effects as an adequate tool to characterize the dynamics of volatility by using the data of five major Latin American markets, over the period February 1992 to December 2015. They found significant and persistent, conditional volatility as well as high, positive and highly significant cross-correlation among these stock markets. Their results confirm higher country risk increases stock market volatility.

Against this backdrop, the objective of this paper is to analyze for the first time in the literature on country risks and stock markets, the role played by aggregate country risk (CR), and its three components: economic risk (ER), financial risk (FR) and political risk (PR) in predicting movements in stock returns and volatility of 83 developed and developing countries. For our purpose, we use the $k$-th order nonparametric causality test of Nishiyama et al. (2011) at monthly frequency over the period of 1984:1 to 2015:12. This test is developed to incorporate higherorder interrelationships inherently based on a nonlinear dependence structure between the investigated variables in question, i.e., between returns and squared returns (with the latter 
measuring volatility) and country risks. Besides squared returns to capture volatility, we also use measure of realized volatility, given that we have daily data on the stock prices of these countries. Our decision to use a nonparametric approach, besides accounting for predictability in returns and volatility, also controls for any possible misspecification of a linear framework of causality, which is likely to (and as we show does) exist in the relationship between stock returns vis-à-vis aggregate and various components of country risks. The remainder of the paper is organized as follows: Section 2 outlines the methodology, while Section 3 discusses the data. Section 4 presents the results of the predictability analysis for returns and volatility, with Section 5 concluding the paper.

\section{Methodology}

In this section, we briefly describe the methodology proposed by Nishiyama et al. (2011), with the test restricted to the case when the examined series follow a stationary nonlinear autoregressive process of order one under the null. Nishiyama et al. (2011) motivated the highorder causality by using the following nonlinear dependence between series

$$
y_{t}=g\left(y_{t-1}\right)+\sigma\left(x_{t-1}\right) \epsilon_{t}
$$

where $\left\{y_{t}\right\}$ and $\left\{x_{t}\right\}$ are stationary time series (i.e., returns and the alternative measures of total risk, and its components: economic, political or financial, which are used in turn as predictors) and $g($.$) and \sigma($.$) are unknown functions which satisfy certain conditions for stationarity. In$ general, $x_{t-1}$ has information in predicting $y_{t}^{K}$ for a given integer $K$. Consequently, the null hypothesis of non-causality in the $K^{\text {th }}$ moment is given by

$$
H_{0}: E\left(y_{t}^{K} \mid y_{t-1}, \ldots, y_{1}, x_{t-1}, \ldots, x_{1}\right)=E\left(y_{t}^{K} \mid y_{t-1}, \ldots, y_{1}\right) \text { w.p. } 1
$$

where w.p. 1 is abbreviation for "with probability one". Formally, we say that $x_{t}$ does not cause $y_{t}$ up to the $K^{\text {th }}$ moment if

$$
H_{0}: E\left(y_{t}^{K} \mid y_{t-1}, \ldots, y_{1}, x_{t-1}, \ldots, y_{1}\right)=E\left(y_{t}^{K} \mid y_{t-1}, \ldots, y_{1}\right) w . p .1 . \quad \text { for all } k=1, \ldots, K
$$

For $k=1$, this definition reduces to non-causality in mean. Nishiyama et al. (2011) note that, it is

easy to construct the test statistic $\hat{S}_{t}^{(k)}$ for each $k=1, \ldots, K$. We implement the test for $k=1$ to test for causality in the $1^{\text {st }}$ moment (non-causality in mean), and for $k=2$ in the $2^{\text {nd }}$ moment (non-causality in variance). The five percent critical value of the test statistic is 14.38 . 
Note that our various measures risks are monthly, hence our causality tests must also be based on monthly returns and squared returns. However, given that we have daily data for stock indices of the countries under consideration, we are able to compute a measure of realized volatility, which in turn, allows us to check the robustness of our findings related to the measure of market volatility (squared returns). The measure that we consider is the classical estimator of realized volatility, i.e. the sum of squared daily returns (Andersen and Bollerslev, 1998), expressed as:

$$
R V_{t}=\sum_{i=1}^{M} y_{t, i}^{2}
$$

where $y_{t, i}$ is the daily $M \times 1$ return vector and $i=1, \ldots, M$ the number of daily returns.

\section{Data}

\subsection{Stock market}

We used data from emerging and developed markets for empirical analysis. The data from the 22 developed and 61 developing markets were used. The stock market data were downloaded from Datastream of Thomson Reuters for both emerging and developed markets for a period of January 1984 to December 2015. All returns are measured in local currency to analyse the impact of political risk on the returns and volatility. Table 1a presents the monthly returns statistics for the developed and emerging markets. We found higher average return of $6.2 \%$ and standard deviation of $16.12 \%$ for Brazil (a typical characteristic. Overall, the descriptive results shows that

the returns and standard deviation are much higher for the emerging markets compared to developed markets. We can observe that average monthly returns of majority of emerging markets are positive except Cyprus, Jordan, Kazakhstan, Ukraine, Vietnam and Zimbabwe. Further, the difference between the minimum and the maximum monthly returns is fairly large, which is further evidence of the higher volatility in the emerging markets. The skewness of the series indicates that the majority of emerging and all of the developed market series are negatively skewed. The kurtosis for the majority of the markets is high showing the distribution of returns has a high peak. This is not surprising as the financial return's distribution has a tendency of be leptokurtic due to volatility clustering (Table 1b).. 
Table 1a: Descriptive Statistics of Monthly Returns

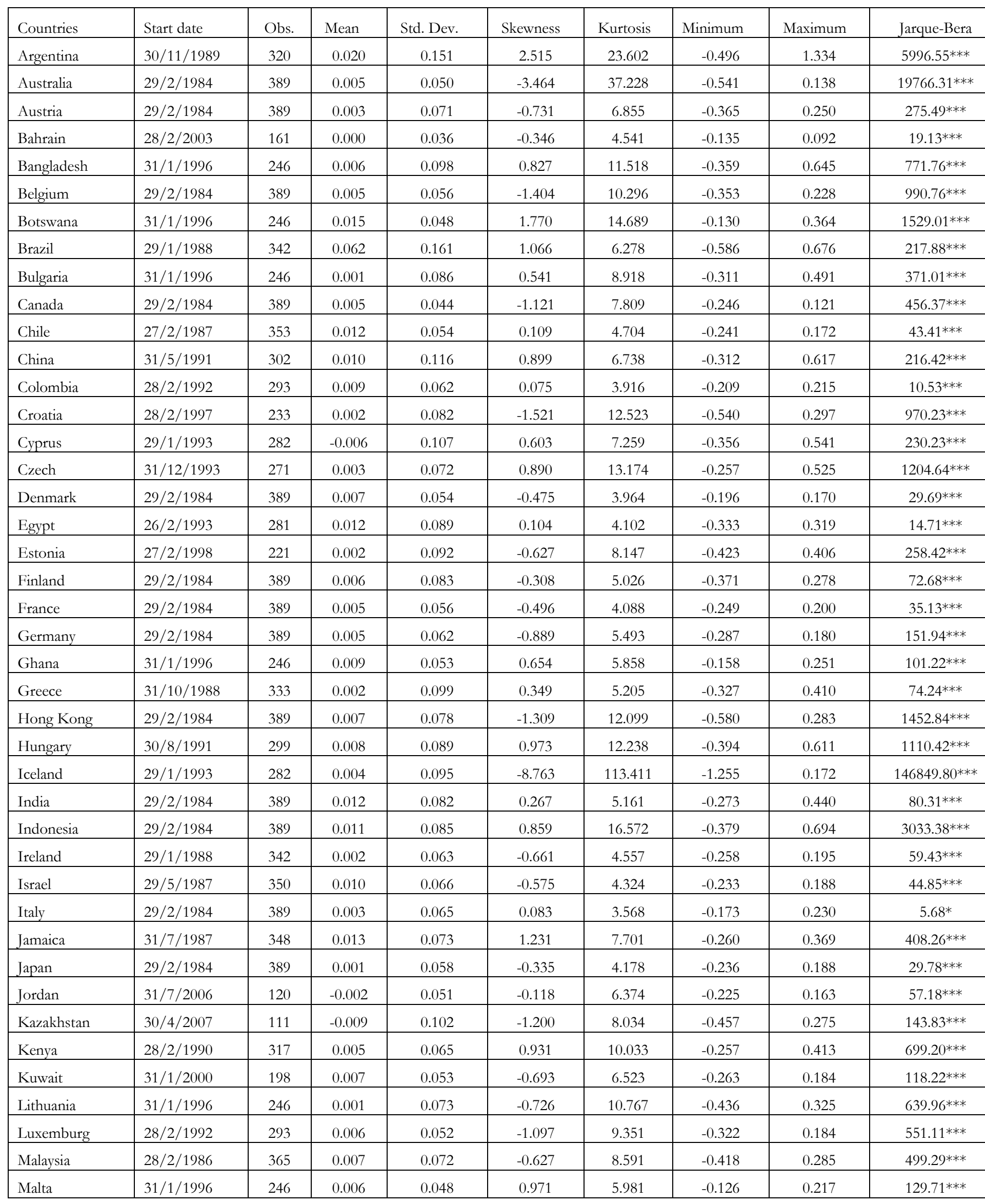




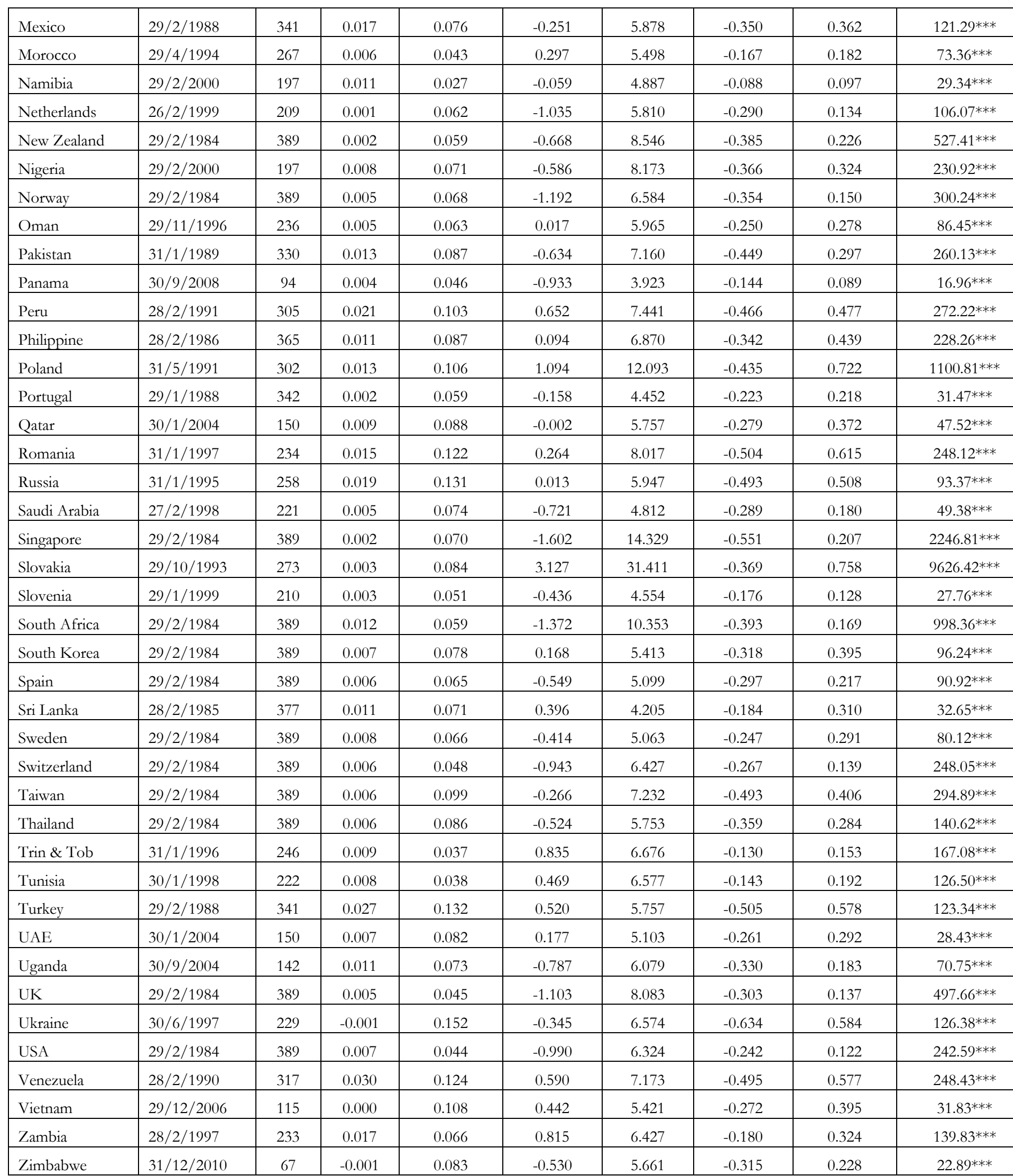

Note: Obs. stands for the number of observations; Std. Dev. stands for standard deviation; ***, and * indicates the rejection of the null of normality of the Jarque-Bera statistic at the significance level of $1 \%$ and $10 \%$ levels respectively. 
Table 1b: Descriptive Statistics of Monthly Risk Indices from ICRG

\begin{tabular}{|c|c|c|c|c|c|c|c|c|}
\hline \multirow{2}{*}{ Countries } & \multicolumn{2}{|c|}{ Political risk } & \multicolumn{2}{|c|}{ Economics risk } & \multicolumn{2}{|c|}{ Financial risk } & \multicolumn{2}{|c|}{ Composite risk } \\
\hline & Mean & Std. Dev. & Mean & Std. Dev. & Mean & Std. Dev. & Mean & Std. Dev. \\
\hline Argentina & 63.24 & 11.71 & 30.69 & 9.26 & 29.83 & 9.66 & 68.22 & 6.09 \\
\hline Australia & 80.41 & 2.34 & 38.81 & 2.06 & 37.79 & 4.57 & 80.05 & 2.16 \\
\hline Austria & 84.39 & 2.93 & 39.97 & 1.71 & 42.47 & 4.20 & 82.78 & 2.75 \\
\hline Bahrain & 72.39 & 7.50 & 40.68 & 3.35 & 38.97 & 5.59 & 76.44 & 4.77 \\
\hline Bangladesh & 56.11 & 10.76 & 32.77 & 4.16 & 31.89 & 9.81 & 62.83 & 1.39 \\
\hline Belgium & 81.19 & 2.83 & 39.81 & 2.62 & 41.32 & 3.88 & 80.57 & 3.37 \\
\hline Botswana & 77.09 & 4.90 & 40.78 & 3.54 & 40.73 & 6.55 & 80.03 & 2.93 \\
\hline Brazil & 64.70 & 6.19 & 30.61 & 6.48 & 33.09 & 5.76 & 68.13 & 4.32 \\
\hline Bulgaria & 66.76 & 5.19 & 31.09 & 5.37 & 33.40 & 4.30 & 69.78 & 2.82 \\
\hline Canada & 83.81 & 1.66 & 40.08 & 2.19 & 42.43 & 3.38 & 83.91 & 1.76 \\
\hline Chile & 72.31 & 10.59 & 36.40 & 6.07 & 37.66 & 5.11 & 77.47 & 2.95 \\
\hline China & 72.06 & 5.68 & 38.30 & 2.93 & 40.97 & 7.57 & 75.51 & 2.34 \\
\hline Colombia & 63.25 & 4.77 & 33.51 & 3.48 & 36.06 & 4.32 & 64.44 & 4.02 \\
\hline Croatia & 71.23 & 2.63 & 35.09 & 2.35 & 34.79 & 2.44 & 71.23 & 2.63 \\
\hline Cyprus & 74.95 & 7.10 & 38.20 & 3.36 & 39.32 & 4.92 & 76.49 & 6.35 \\
\hline Czech & 76.94 & 2.82 & 36.82 & 2.76 & 38.89 & 2.29 & 76.14 & 1.79 \\
\hline Denmark & 84.69 & 2.50 & 40.55 & 2.80 & 43.01 & 2.74 & 84.65 & 2.57 \\
\hline Egypt & 61.77 & 9.46 & 31.72 & 5.15 & 35.10 & 8.12 & 65.49 & 4.39 \\
\hline Estonia & 72.25 & 3.47 & 37.64 & 2.98 & 32.41 & 4.85 & 72.24 & 3.47 \\
\hline Finland & 84.55 & 3.24 & 39.80 & 4.76 & 39.37 & 3.87 & 85.12 & 3.62 \\
\hline France & 78.52 & 3.56 & 38.43 & 2.72 & 40.55 & 3.71 & 76.45 & 3.59 \\
\hline Germany & 83.46 & 1.69 & 40.73 & 2.12 & 42.46 & 3.64 & 83.33 & 1.55 \\
\hline Ghana & 60.68 & 7.51 & 29.14 & 3.09 & 31.79 & 5.33 & 64.77 & 4.15 \\
\hline Greece & 68.32 & 6.59 & 33.54 & 4.03 & 32.31 & 3.63 & 70.44 & 5.38 \\
\hline Hong Kong & 79.00 & 5.50 & 41.56 & 3.98 & 42.09 & 2.71 & 82.29 & 2.76 \\
\hline Hungary & 71.65 & 4.62 & 32.55 & 4.10 & 34.10 & 3.65 & 73.16 & 2.89 \\
\hline Iceland & 78.53 & 4.98 & 34.99 & 5.87 & 35.65 & 6.01 & 77.24 & 6.18 \\
\hline India & 63.10 & 7.96 & 32.76 & 2.72 & 37.03 & 6.51 & 67.94 & 2.76 \\
\hline Indonesia & 61.42 & 8.47 & 34.64 & 4.00 & 34.87 & 7.23 & 63.28 & 5.96 \\
\hline Ireland & 81.28 & 4.97 & 39.33 & 4.20 & 39.64 & 4.03 & 81.44 & 6.12 \\
\hline Israel & 66.71 & 8.54 & 36.77 & 4.12 & 36.96 & 5.03 & 71.36 & 2.89 \\
\hline Italy & 77.10 & 3.38 & 37.63 & 2.35 & 40.06 & 3.95 & 76.12 & 3.49 \\
\hline Jamaica & 65.92 & 6.63 & 29.16 & 3.09 & 33.58 & 5.61 & 68.19 & 2.69 \\
\hline Japan & 85.01 & 3.54 & 40.41 & 2.84 & 46.49 & 2.84 & 82.66 & 2.36 \\
\hline Jordan & 65.76 & 9.39 & 34.46 & 3.71 & 34.25 & 7.15 & 70.57 & 3.33 \\
\hline Kazakhstan & 71.36 & 3.25 & 36.71 & 4.05 & 35.97 & 3.23 & 71.36 & 3.25 \\
\hline Kenya & 60.45 & 4.72 & 30.43 & 2.90 & 33.57 & 5.15 & 62.71 & 2.26 \\
\hline Kuwait & 74.99 & 11.93 & 43.33 & 5.35 & 41.39 & 8.21 & 82.17 & 3.25 \\
\hline Lithuania & 73.04 & 3.02 & 36.60 & 3.15 & 36.09 & 3.23 & 73.04 & 3.02 \\
\hline Luxemburg & 89.40 & 1.70 & 41.64 & 3.48 & 44.99 & 3.24 & 88.87 & 1.79 \\
\hline Malaysia & 75.60 & 5.08 & 39.90 & 2.59 & 39.98 & 5.30 & 77.40 & 2.50 \\
\hline
\end{tabular}




\begin{tabular}{|c|c|c|c|c|c|c|c|c|}
\hline Malta & 77.01 & 5.74 & 38.38 & 4.21 & 37.26 & 3.86 & 78.17 & 2.11 \\
\hline Mexico & 69.22 & 6.13 & 33.15 & 4.68 & 36.38 & 6.16 & 72.71 & 3.14 \\
\hline Morocco & 66.34 & 9.82 & 33.85 & 3.32 & 35.25 & 6.96 & 72.01 & 2.72 \\
\hline Namibia & 73.72 & 8.04 & 36.68 & 3.90 & 36.70 & 6.55 & 76.48 & 2.90 \\
\hline Netherlands & 85.52 & 3.20 & 41.57 & 2.09 & 42.07 & 4.34 & 83.66 & 2.85 \\
\hline New Zealand & 81.12 & 2.44 & 37.69 & 2.73 & 37.83 & 6.62 & 79.74 & 1.84 \\
\hline Nigeria & 55.77 & 7.51 & 31.51 & 5.15 & 34.05 & 10.66 & 60.69 & 4.46 \\
\hline Norway & 89.23 & 2.49 & 44.89 & 2.74 & 46.34 & 1.34 & 90.51 & 1.71 \\
\hline Oman & 75.00 & 8.07 & 39.94 & 4.86 & 40.34 & 5.49 & 80.41 & 2.88 \\
\hline Pakistan & 54.80 & 6.13 & 32.08 & 2.03 & 31.67 & 6.66 & 57.95 & 2.81 \\
\hline Panama & 66.15 & 8.97 & 36.44 & 1.36 & 32.53 & 5.38 & 73.02 & 1.16 \\
\hline Peru & 60.27 & 13.24 & 32.31 & 7.15 & 32.80 & 10.14 & 70.43 & 2.08 \\
\hline Philippine & 63.10 & 11.06 & 34.57 & 4.35 & 33.90 & 8.39 & 70.29 & 1.85 \\
\hline Poland & 69.81 & 11.18 & 33.13 & 6.20 & 33.95 & 7.09 & 75.37 & 1.65 \\
\hline Portugal & 76.17 & 4.73 & 36.44 & 3.34 & 37.36 & 4.15 & 75.50 & 4.15 \\
\hline Qatar & 71.85 & 9.35 & 41.12 & 6.73 & 35.51 & 6.00 & 77.86 & 4.88 \\
\hline Romania & 62.34 & 7.48 & 29.37 & 4.99 & 30.98 & 6.88 & 67.01 & 4.21 \\
\hline Russia & 67.35 & 8.34 & 36.42 & 6.72 & 38.19 & 7.18 & 70.07 & 7.69 \\
\hline Saudi Arabia & 72.32 & 8.71 & 40.13 & 4.77 & 40.65 & 7.87 & 77.82 & 3.80 \\
\hline Singapore & 85.72 & 3.89 & 43.64 & 3.89 & 44.80 & 2.78 & 87.67 & 2.12 \\
\hline Slovakia & 74.36 & 2.27 & 36.01 & 3.37 & 36.53 & 1.87 & 74.13 & 1.86 \\
\hline Slovenia & 75.00 & 4.81 & 36.66 & 2.89 & 35.80 & 4.52 & 75.01 & 4.81 \\
\hline South Africa & 67.75 & 5.83 & 34.62 & 2.14 & 35.53 & 4.58 & 69.93 & 2.37 \\
\hline South Korea & 77.83 & 5.13 & 40.09 & 3.15 & 41.77 & 4.77 & 79.73 & 2.04 \\
\hline Spain & 75.11 & 4.14 & 37.31 & 2.72 & 38.37 & 3.29 & 74.92 & 4.79 \\
\hline Sri Lanka & 57.37 & 8.58 & 31.61 & 3.17 & 32.00 & 6.56 & 62.06 & 2.15 \\
\hline Sweden & 84.54 & 2.06 & 41.07 & 3.51 & 40.91 & 3.73 & 85.26 & 1.84 \\
\hline Switzerland & 90.11 & 2.49 & 43.41 & 1.80 & 47.27 & 2.51 & 88.99 & 1.84 \\
\hline Taiwan & 82.93 & 1.94 & 42.45 & 1.99 & 45.82 & 2.40 & 82.72 & 1.35 \\
\hline Thailand & 69.66 & 5.15 & 37.42 & 2.91 & 39.39 & 4.86 & 70.69 & 3.32 \\
\hline Trin \&Toba & 71.17 & 8.32 & 36.73 & 4.81 & 39.32 & 6.65 & 77.59 & 2.89 \\
\hline Tunisia & 65.93 & 8.63 & 33.64 & 3.47 & 33.07 & 5.77 & 70.28 & 4.02 \\
\hline Turkey & 58.60 & 6.29 & 29.87 & 3.88 & 30.20 & 5.45 & 61.24 & 4.38 \\
\hline UAE & 74.04 & 11.09 & 42.76 & 3.50 & 37.61 & 7.63 & 82.01 & 2.70 \\
\hline Uganda & 53.53 & 11.64 & 27.75 & 8.84 & 29.98 & 8.28 & 61.76 & 2.36 \\
\hline UK & 80.79 & 3.46 & 36.98 & 2.71 & 42.08 & 5.06 & 79.56 & 3.76 \\
\hline Ukraine & 64.94 & 5.47 & 31.76 & 5.16 & 35.18 & 4.77 & 64.90 & 5.56 \\
\hline USA & 80.52 & 4.37 & 38.13 & 2.16 & 40.10 & 7.43 & 77.23 & 2.85 \\
\hline Venezuela & 62.94 & 5.65 & 31.67 & 5.50 & 36.62 & 6.67 & 61.45 & 5.82 \\
\hline Vietnam & 61.19 & 10.98 & 29.36 & 6.87 & 31.07 & 9.11 & 68.73 & 2.68 \\
\hline Zambia & 56.72 & 9.65 & 27.27 & 5.36 & 27.33 & 8.36 & 62.83 & 6.16 \\
\hline Zimbabwe & 49.05 & 7.95 & 23.01 & 6.75 & 25.77 & 3.60 & 44.59 & 6.44 \\
\hline
\end{tabular}

Note: The Index of political risk and composite risk is between 0 and 100 and between 0 and 50 for economic and financial risk. A higher value represents a lower risk in a country. The table includes mean which is the average risk rating, and Std. Dev. Which is standard deviation. 


\subsection{Country risk}

Political risk is a qualitative measure and for analysing its contribution to financial data, we need to quantify it. A number of institutions such as the Bank of America, Business Environment Risk Intelligence, Economist Intelligence Unit, Euromoney, Institutional Investor, Standard and Poor's Rating Group, Political Risk Service Group, Coplin-O'Leary Ratings system and Moody's Investment Service offer country-by-country analysis of political risk. However, few of these agencies or institutes provide quantitative analysis and most of them are on a semi-annual or annual basis. Since January 1984, the ICRG has been compiling economic, financial, political and composite risk ratings for over 90 countries on a monthly basis. As of December 2014, these four risk ratings were available for a total of 140 countries. This study employs political risk indices developed by the ICRG and compiled by the PRGS Group ${ }^{1}$.

According to the ICRG, their risk ratings have been cited by experts at the IMF, World Bank, United Nations, and other international institutions as a standard against which other ratings can be measured. The ICRG has been acclaimed by publications such as Barron's and The Wall Street Journal for the strength of its analysis and rating system. For example, Howell and Chaddick (1994) found that ICRG indices are more reliable and are able to predict risk better than other major political risk information providers. Hoti and McAleer (2005) examined the qualitative comparison of the country risk rating system used by seven leading agencies and found that ICRG is the best one to forecast the political, financial and economic risk. More recently, Bekaert, Harvey, Lundblad, and Siegel (2014) found that risk ratings from ICRG predict the political events well and that political risk ratings provided by ICRG can be used as an alternative to political events.

We used the data from ICRG for the period of January 1984 to December 2015 for both emerging and developed markets. ICRG provide four types of indices including political risk index, economic risk index, financial risk index and composite risk index. The composite risk is the weighted average of all the three risks (political, economic and financial risk) and calculated as: composite $=0.5^{*}$ (political risk + economic risk + financial risk). Political risk compounds the degree of political uncertainty in a given country and consists of twelve components, whereas financial and economic risk consists of five subcomponents each. The maximum number of 100 reflects the lowest risk, and a score of zero is the highest risk. We also use economic risk which is a measure of assessing a country's current economic strengths and weaknesses. The economic risk

\footnotetext{
1 The PRS Group, Inc in East Syracuse, New York has published its International Country Risk Guide which has provided financial, political and economic risk ratings for 140 countries since 1984.
} 
consists of five components which include per capita GDP, the real GDP growth rate, inflation, and fiscal and current account balances expressed as a percentage of GDP. The rating of economic risk is between 0 and 50 and a high rating indicates sound economic conditions whereas a low rating demonstrates weak economic conditions in the country. The overall aim of the financial risk is to provide a measure of a country's ability to finance its official, commercial, and trade debt obligations. This also consists of five subcomponents like economic risk which is external debt as a percentage of GDP, foreign debt as percentage of export of goods and services, current accounts as a percentage of goods and services, net liquidity in a month, and exchange rate stability against the US dollar. The financial risk fluctuates between 0 and 50, a high rating display a low level of external exposure and vice versa.

The descriptive statistics of monthly political risk, financial risk, economic risk and composite risk for the emerging and developed markets are presented in Table1a. Majority of the emerging markets are with low average political risk, (means high political risky countries) such as Zimbabwe, Uganda and Pakistan. The highest political rating is for Switzerland for developed markets (average rating of 90). For the economic risk the lowest score is for Vietnam, Zambia, and Zimbabwe. Whereas, developed markets are with high rating confirming good conditions in these markets. Similar results found for the financial risk majority of the emerging markets are with low score compared to the developed. The composite risk is lowest for Zimbabwe and Pakistan. Overall we find higher standard deviation for emerging markets than developed markets. This shows that there is more uncertainty in emerging markets. Since our methodology requires stationary data, and the country risk-ratings were non-stationary, we work with the firstdifferences of their natural logs to ensure that the ratings are mean reverting. ${ }^{2}$

\section{Empirical Results}

Though our objective is to analyse the $k$-th order causality running from the various risk measures on stock returns and volatility of the 83 countries, for the sake of completeness and comparability, we also conducted the standard linear Granger causality test based on a VAR(1) model. The results have been reported in Table 2a. The decision to use a model of order one is to be not only consistent with the lag-length choice of the Nishiyama et al., (2011) test, but also, we are in line with the stock returns predictability literature (see Rapach et al., 2005). As can be seen, barring seven cases under the aggregate country risk, four under economic risks, ten under

\footnotetext{
${ }^{2}$ Complete details of the unit root tests are available upon request from the authors.
} 
financial risks and six under political risks, there is no evidence of causality running from the various risks on stock returns of the 83 economies at the conventional 5 percent level of significance. The names of the countries which show predictability have been summarized in Table 2b.

Table 2a: Linear Granger Causality Test of Stock Returns

\begin{tabular}{|c|c|c|c|c|}
\hline Country & CR & ER & FR & PR \\
\hline Argentina & 0.017 & 0.635 & 1.303 & 0.679 \\
\hline Austria & 0.458 & 0.802 & 0.935 & 0.005 \\
\hline Australia & 0.000 & 0.051 & 0.101 & 0.384 \\
\hline Bahrain & 0.000 & 0.355 & 0.318 & 0.988 \\
\hline Bangladesh & 2.323 & 0.05 & 0.973 & $5.667^{*}$ \\
\hline Belgium & 0.831 & 3.56 & 0.716 & 0.672 \\
\hline Botswana & 3.767 & 0.981 & 2.475 & 0.894 \\
\hline Brazil & 0.168 & 0.009 & 0.151 & 3.004 \\
\hline Bulgaria & 2.166 & 3.86 & 0.308 & 0.108 \\
\hline Canada & 0.124 & 0.036 & 0.855 & 0.06 \\
\hline Chile & $8.412^{*}$ & 0.425 & 2.86 & $10.879^{*}$ \\
\hline China & 2.393 & 1.026 & $14.029^{*}$ & 0.974 \\
\hline Colombia & 1.403 & 0.891 & 1.831 & 0.079 \\
\hline Croatia & $5.927^{*}$ & 0.573 & $9.562^{*}$ & 0.101 \\
\hline Cyprus & 0.602 & 0.314 & 1.249 & 0.341 \\
\hline Czech Republic & 0.02 & 1.196 & 0.477 & 0.004 \\
\hline Denmark & 0.022 & 0.081 & 0.369 & 0.265 \\
\hline Egypt & 1.122 & 0.907 & 0.062 & 0.111 \\
\hline Estonia & 0.371 & 0.263 & 0.373 & 0.004 \\
\hline Finland & 1.493 & 2.702 & 0.571 & 0.05 \\
\hline France & 0.064 & 0.081 & 0.518 & 0.199 \\
\hline Germany & 0.942 & 0.003 & 0.245 & 1.405 \\
\hline Ghana & 0.029 & 0.838 & 0.249 & 0.045 \\
\hline Greece & 2.567 & 0.767 & 1.649 & 0.009 \\
\hline Hong Kong & 0.095 & 0.402 & 0.017 & 0.234 \\
\hline Hungary & 0.171 & 0.083 & 0.441 & 2.435 \\
\hline Iceland & $4.41^{*}$ & $3.948^{*}$ & $4.975^{*}$ & 0.213 \\
\hline India & 1.365 & 0.001 & 3.205 & 0.532 \\
\hline Indonesia & 0.285 & 0.01 & 0.725 & 1.746 \\
\hline Ireland & 0.002 & 0.04 & 0.981 & 0.029 \\
\hline Israel & 2.15 & 0.483 & 0.403 & 1.712 \\
\hline Italy & 3.83 & 0.717 & 1.885 & 1.427 \\
\hline Jamaica & 0.002 & 0.01 & 0.08 & 0.01 \\
\hline Japan & 0.15 & 0.03 & 1.975 & 0.000 \\
\hline Jordan & $14.337^{*}$ & $14.691^{*}$ & 1.033 & 0.854 \\
\hline Kazakhstan & 0.192 & 0 & 0 & $4.764^{*}$ \\
\hline Kenya & 0.184 & 0.673 & 0.38 & 0.049 \\
\hline Kuwait & 0.026 & 0.222 & 0.552 & 0.585 \\
\hline Lithuania & 1.664 & 0.126 & $4.816^{*}$ & 1.496 \\
\hline Luxembourg & 0.416 & 0.224 & 0.182 & 1.53 \\
\hline Malaysia & 2.166 & 0.089 & $10.436^{*}$ & 0.087 \\
\hline Malta & 1.436 & 1.073 & 0.173 & 1.267 \\
\hline Mexico & $13.233^{*}$ & 0.73 & $12.365^{*}$ & $6.203^{*}$ \\
\hline Morocco & 1.965 & 0.279 & 0.62 & 2.694 \\
\hline Namibia & 0.013 & 0.007 & 0.15 & 0.188 \\
\hline Netherlands & 3.251 & 2.479 & 3.229 & 0.229 \\
\hline New Zealand & 3.142 & 0.021 & 2.872 & 1.504 \\
\hline Nigeria & 0.112 & 0.019 & 0.644 & 0.176 \\
\hline
\end{tabular}




\begin{tabular}{|c|c|c|c|c|}
\hline Norway & 0.147 & 0.713 & 0.104 & 0.434 \\
\hline Oman & 0.302 & 0.007 & $4.462^{*}$ & 0.35 \\
\hline Pakistan & 0.199 & 1.206 & 3.043 & 1.304 \\
\hline Panama & 0.698 & 0.895 & 0.143 & 0.139 \\
\hline Peru & 0.483 & 0.803 & $5.223^{*}$ & 0.747 \\
\hline Philippines & 1.277 & 0.719 & 1.569 & 0.059 \\
\hline Poland & 0.619 & 1.799 & 0.909 & 3.878 \\
\hline Portugal & 1.909 & 0.741 & 2.46 & 0.157 \\
\hline Qatar & 0.368 & 0.016 & 2.323 & 0 \\
\hline Romania & 0.007 & 0.431 & 0.393 & 0.414 \\
\hline Russia & 3.01 & 1.335 & $9.909^{*}$ & 0.224 \\
\hline Saudi Arabia & 1.042 & 0.88 & 0.354 & 0.004 \\
\hline Singapore & 0.457 & 0.308 & 0.343 & 0.075 \\
\hline Slovakia & 0.88 & 0.61 & 0.358 & 2.319 \\
\hline Slovenia & 0.399 & 0.15 & 0.241 & 0.273 \\
\hline South Africa & 0.143 & 0.2 & 0.089 & 0.171 \\
\hline South Korea & 0.454 & 0.065 & 0.662 & 0.027 \\
\hline Spain & 0.67 & 2.015 & 0.048 & 0.485 \\
\hline Sri Lanka & 0.158 & 0.006 & 0.963 & 0.73 \\
\hline Sweden & 0.547 & 0.094 & $4.744^{*}$ & 0.567 \\
\hline Switzerland & 0.029 & 0.044 & 0.002 & 0.122 \\
\hline Taiwan & 1.764 & 3.668 & 0.922 & 0.059 \\
\hline Thailand & 0.516 & 0.93 & 2.401 & 0.719 \\
\hline Trinidad \& Tobago & $5.251^{*}$ & 1.516 & 0.072 & 3.534 \\
\hline Tunisia & 0.106 & 0.347 & 0.646 & 2.236 \\
\hline Turkey & 2.428 & 0.36 & 3.809 & 0.119 \\
\hline UAE & 0.632 & 0.265 & 0.395 & 0.311 \\
\hline Uganda & 0.001 & 0.39 & 0.044 & 0.813 \\
\hline United Kingdom & 2.137 & $5.358^{*}$ & 0.576 & 1.725 \\
\hline Ukraine & 3.035 & $12.587^{*}$ & 3.636 & $5.503^{*}$ \\
\hline United States & $4.625^{*}$ & 1.209 & 0.218 & $4.159^{*}$ \\
\hline Venezuela & 2.156 & 0.006 & 1.371 & 3.65 \\
\hline Vietnam & 0.121 & 0.001 & 0.005 & 0.954 \\
\hline Zambia & 0.835 & 0.044 & 0.622 & 1.197 \\
\hline Zimbabwe & 0.022 & 0.028 & 0.000 & 0.107 \\
\hline
\end{tabular}

Note: Value in cell is the F-statistic and * represents rejection of the null of non-causality from various measures of risk on stock returns at the significance level of 5\%; CR: Aggregate country risk; ER: Economic risk; FR: Financial risk; PR: Political risk.

Table 2b: Summary Linear Causality Test

\begin{tabular}{|l|l|l|l|l|}
\hline & CR & ER & FR & PR \\
\hline Returns & Chile & Iceland & China & Bangladesh \\
& Croatia & Jordan & Croatia & Chile \\
& Iceland & United Kingdom & Iceland & Kazakhstan \\
& Jordan & Ukraine & Lithuania & Mexico \\
& Mexico & & Malaysia & Ukraine \\
& Trinidad \& & & Mexico & \\
& Tobago & & Onited States \\
& United States & & Peru & \\
& & & Russia & \\
& & & Sweden & \\
\hline
\end{tabular}

Note: See Notes to Table 2a.

Next, to motivate the use of the nonparametric causality approach, we statistically investigate the possibility of nonlinearity in the stock returns, and in its relationship with the measure of the geopolitical risk. To this end, we apply the Brock et al., (1996, BDS) test on the residuals of the 
stock returns equation in the various $\operatorname{VAR}(1)$ models of stock returns and the four risk measures (i.e., aggregate and three of its components). As reported in Table 3, the results provide ample evidence of the rejection of the null of i.i.d. residuals at various embedded dimensions $(m)$, for all cases considered. These results provide strong evidence of nonlinearity in the relationship between stock returns and measures of risks. This means that, the results based on the linear Granger causality test cannot be deemed robust and reliable.

Table 3: Brock et al.,'s (1996, BDS) Test of Nonlinearity on residuals for the stock returns equation in a VAR (1) model of stock returns and the measure of risk

\begin{tabular}{|c|c|c|c|c|c|}
\hline \multirow[t]{2}{*}{ Country/ Ratings } & \multicolumn{5}{|c|}{ Dimension } \\
\hline & 2 & 3 & 4 & 5 & 6 \\
\hline \multicolumn{6}{|l|}{ ARGENTINA } \\
\hline $\mathrm{CR}$ & $4.854^{* * *}$ & $5.552^{* * *}$ & $5.703^{* * *}$ & $5.917^{* * *}$ & $6.531^{* * *}$ \\
\hline ER & $4.727^{* * *}$ & $5.493^{* * *}$ & $5.626^{* * *}$ & $5.849^{* * *}$ & $6.493^{* * *}$ \\
\hline FR & $4.6^{* * *}$ & $5.524^{* * *}$ & $5.672^{* * *}$ & $5.901^{* * *}$ & $6.424^{* * *}$ \\
\hline PR & $4.906^{* * *}$ & $5.52^{* * *}$ & $5.623^{* * *}$ & $5.81^{* * *}$ & $6.39^{* * *}$ \\
\hline \multicolumn{6}{|l|}{ AUSTRIA } \\
\hline $\mathrm{CR}$ & $2.556^{* *}$ & $3.424^{* * *}$ & $3.406^{* * *}$ & $3.811^{* * *}$ & $3.979^{* * *}$ \\
\hline ER & $2.582^{* *}$ & $3.519^{* * *}$ & $3.532^{* * *}$ & $4.007^{* * *}$ & $4.199^{* * *}$ \\
\hline FR & $2.565^{* *}$ & $3.537^{* * * *}$ & $3.535^{* * *}$ & $3.933^{* * *}$ & $4.126^{* * *}$ \\
\hline PR & $2.562^{* *}$ & $3.462^{* * *}$ & $3.511^{* * *}$ & $3.934^{* * *}$ & $4.089^{* * *}$ \\
\hline \multicolumn{6}{|l|}{ AUSTRALIA } \\
\hline $\mathrm{CR}$ & 1.390 & $4.025^{* * *}$ & $-8.002^{* * *}$ & $-4.944^{* * *}$ & $-3.343^{* * *}$ \\
\hline ER & $4.394^{* * *}$ & $-10.139^{* * *}$ & $-4.896^{* * *}$ & $-2.780^{* *}$ & $-1.725^{*}$ \\
\hline FR & $-4.537^{* * *}$ & $43.769^{* * *}$ & $-5.086^{* * *}$ & $-2.879^{* *}$ & $-1.785^{*}$ \\
\hline $\mathrm{PR}$ & $-4.711^{* * *}$ & $7.566^{* * *}$ & $-10.757^{* * *}$ & $-6.819^{* * *}$ & $-4.767^{* * *}$ \\
\hline \multicolumn{6}{|l|}{ BAHRAIN } \\
\hline $\mathrm{CR}$ & $1.929^{*}$ & $2.412^{* *}$ & $3.706^{* * *}$ & $2.704^{* *}$ & $-1.915^{*}$ \\
\hline ER & $2.036^{* *}$ & $3.550^{* * *}$ & $5.215^{* * *}$ & $2.921^{* *}$ & $-1.963^{*}$ \\
\hline FR & $1.830^{*}$ & $2.311^{* *}$ & $-3.357^{* * *}$ & $-2.014^{* *}$ & -1.285 \\
\hline PR & $\begin{array}{l}-0.746 \\
\end{array}$ & $-5.338^{* * *}$ & $-4.443^{* * *}$ & $-2.709^{* *}$ & $-1.798^{*}$ \\
\hline \multicolumn{6}{|l|}{ BANGLADESH } \\
\hline $\mathrm{CR}$ & $5.149^{* * *}$ & $5.872^{* * *}$ & $6.113^{* * *}$ & $5.996^{* * *}$ & $5.914^{* * *}$ \\
\hline ER & $5.026^{* * *}$ & $5.849^{* * *}$ & $6.113^{* * *}$ & $5.914^{* * *}$ & $5.771^{* * *}$ \\
\hline FR & $4.758^{* * *}$ & $5.76^{* * *}$ & $6.098^{* * *}$ & $6.01^{* * *}$ & $5.886^{* * *}$ \\
\hline PR & $4.902^{* * *}$ & $5.656^{* * *}$ & $5.956^{* * *}$ & $5.854^{* * *}$ & $5.843^{* * *}$ \\
\hline \multicolumn{6}{|l|}{ BELGIUM } \\
\hline $\mathrm{CR}$ & $1.767^{*}$ & $2.27^{* * *}$ & $2.057^{* *}$ & $2.722^{* *}$ & $2.639^{* *}$ \\
\hline ER & $2.163^{* *}$ & $2.661^{* *}$ & $2.372^{* *}$ & $3.004^{* *}$ & $2.887^{* *}$ \\
\hline FR & $1.998^{* *}$ & $2.43^{* *}$ & $2.176^{* *}$ & $2.817^{* *}$ & $2.735^{* *}$ \\
\hline PR & $2.432^{* *}$ & $2.888^{* *}$ & $2.717^{* *}$ & $3.462^{* * *}$ & $3.476^{* * *}$ \\
\hline \multicolumn{6}{|l|}{ BOTSWANA } \\
\hline $\mathrm{CR}$ & $2.806^{* *}$ & $3.65^{* * *}$ & $3.618^{* * *}$ & $3.472^{* * *}$ & $3.725^{* * *}$ \\
\hline ER & $2.996^{* *}$ & $3.805^{* * *}$ & $3.817^{* * * *}$ & $3.73^{* * *}$ & $4.049^{* * *}$ \\
\hline FR & $2.217^{* *}$ & $3.231^{* * *}$ & $3.352^{* * *}$ & $3.257^{* * *}$ & $3.525^{* * *}$ \\
\hline PR & $3.278^{* * *}$ & $4.087^{* * *}$ & $4.075^{* * *}$ & $3.954^{* * *}$ & $4.248^{* * *}$ \\
\hline \multicolumn{6}{|l|}{ BRAZIL } \\
\hline $\mathrm{CR}$ & $6.5^{* * *}$ & $10.379^{* * *}$ & $12.832^{* * *}$ & $14.757^{* * *}$ & $16.612^{* * *}$ \\
\hline ER & $6.381^{* * *}$ & $10.25^{* * *}$ & $12.686^{* * *}$ & $14.578^{* * *}$ & $16.393^{* * *}$ \\
\hline FR & $6.461^{* * *}$ & $10.324^{* * *}$ & $12.781^{* * *}$ & $14.708^{* * *}$ & $16.557^{* * *}$ \\
\hline PR & $6.331^{* * *}$ & $10.142^{* * *}$ & $12.509^{* * *}$ & $14.398^{* * *}$ & $16.162^{* * *}$ \\
\hline
\end{tabular}




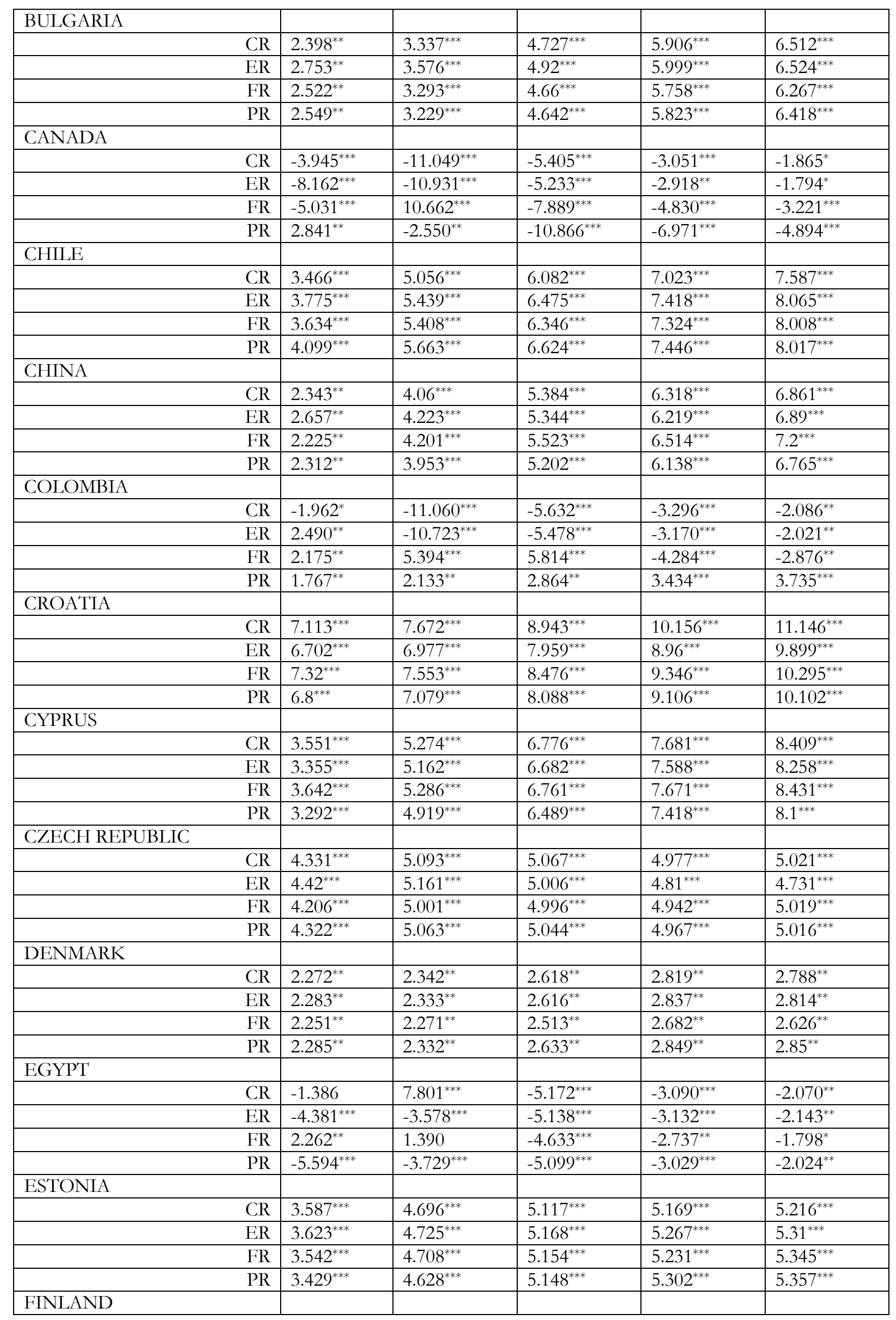




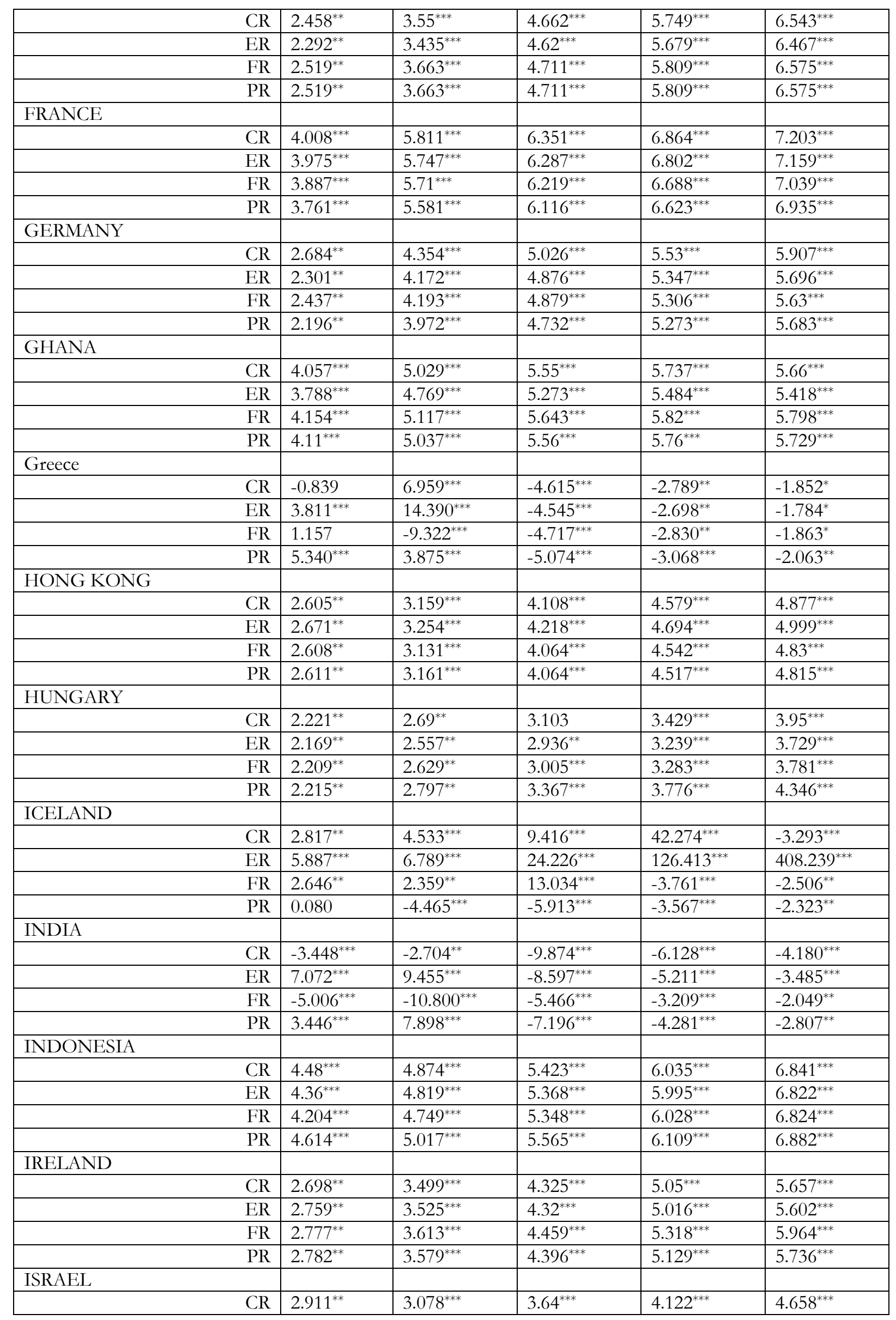




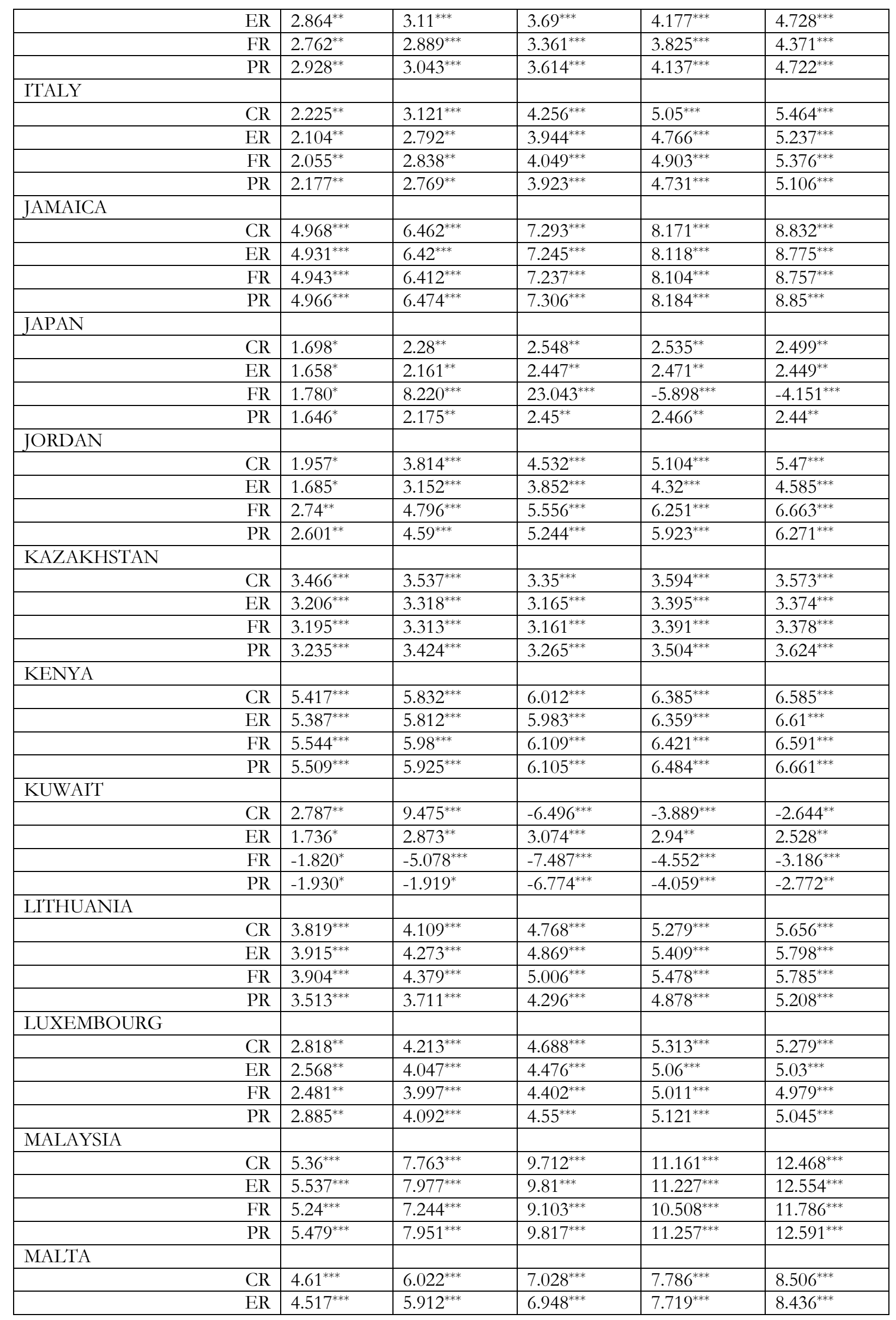




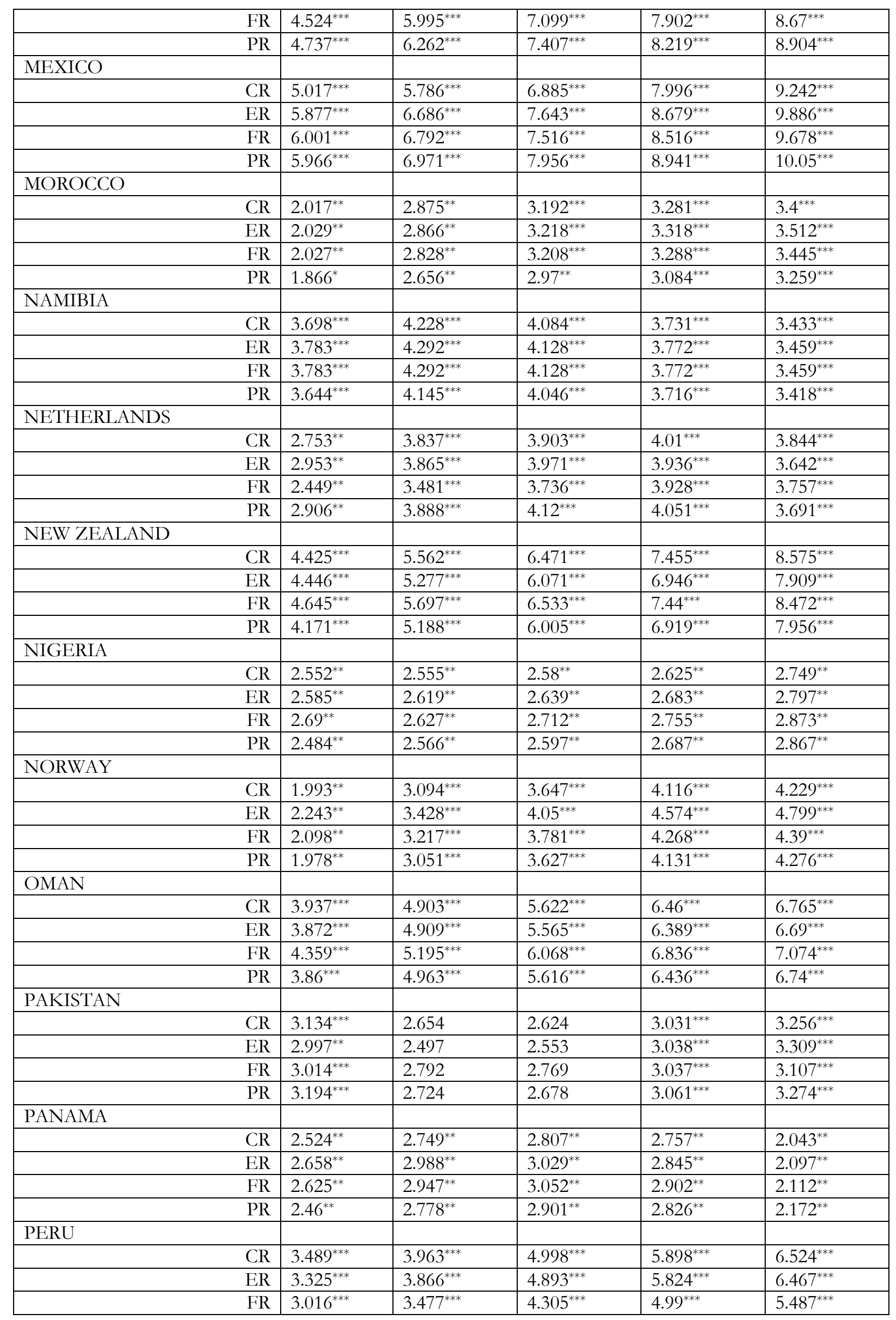




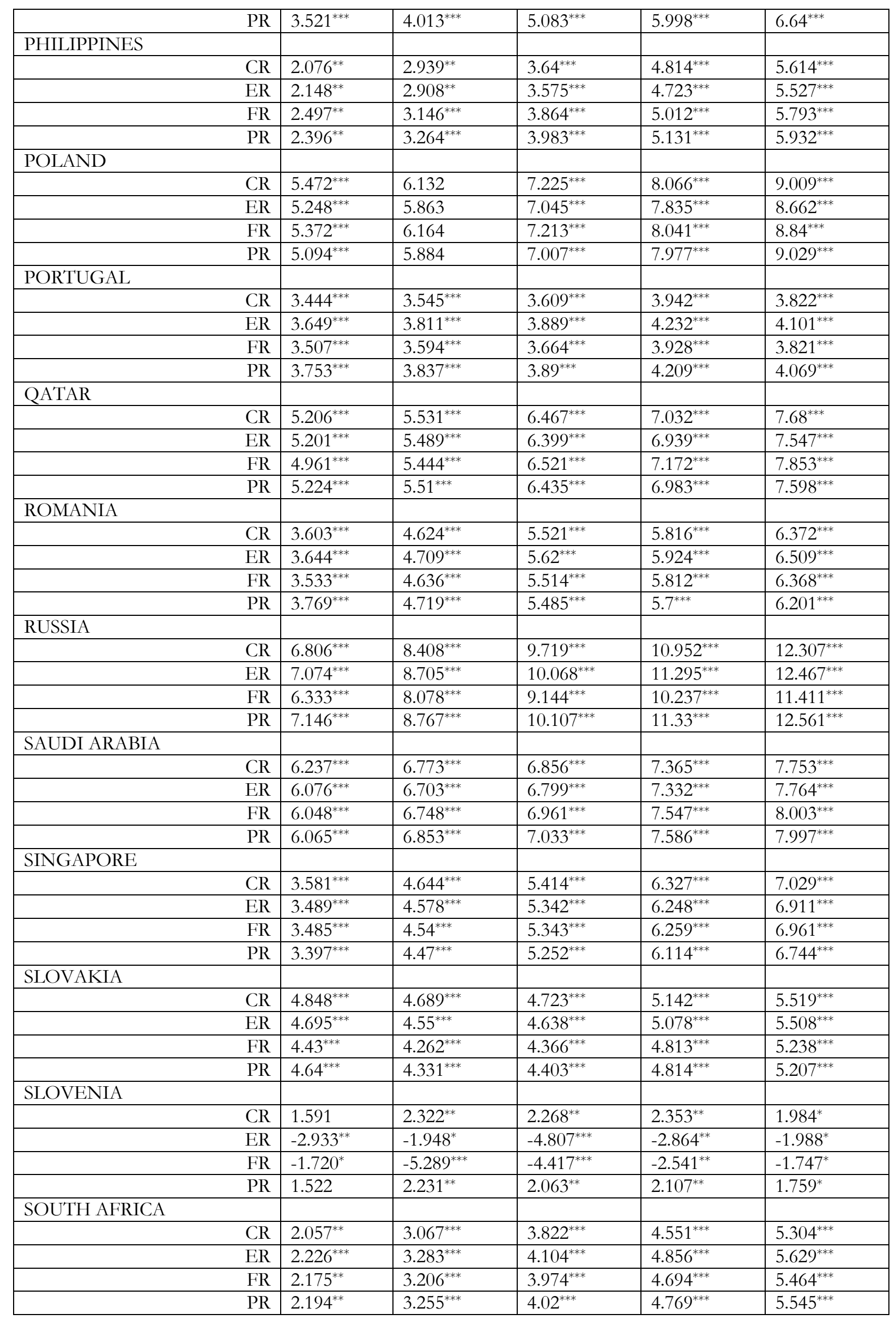




\begin{tabular}{|c|c|c|c|c|c|}
\hline \multicolumn{6}{|l|}{ SOUTH KOREA } \\
\hline $\mathrm{C}$ & $2.395^{* *}$ & $3.664^{* * *}$ & $4.52^{* * *}$ & $5.423^{* * *}$ & $6.221^{* * *}$ \\
\hline E & $2.377^{* *}$ & $3.621^{* * *}$ & $4.469^{* * *}$ & $5.397^{* * *}$ & $6.185^{* * *}$ \\
\hline $\mathrm{F}$ & $2.362^{* *}$ & $3.563^{* * *}$ & $4.428^{* * *}$ & $5.362^{* * *}$ & $6.191^{* * *}$ \\
\hline $\bar{P}$ & $2.306^{* *}$ & $3.54^{* * *}$ & $4.377^{* * *}$ & $5.3^{* * *}$ & $6.077^{* * *}$ \\
\hline \multicolumn{6}{|l|}{ SPAIN } \\
\hline $\mathrm{C}$ & $2.771^{* *}$ & $3.069^{* * *}$ & $3.27^{* * *}$ & $3.747^{* * *}$ & $4.183^{* * *}$ \\
\hline E & $2.934^{* *}$ & $3.169^{* * *}$ & $3.351^{* * *}$ & $3.782^{* * *}$ & $4.194^{* * *}$ \\
\hline $\mathrm{F}$ & $2.799^{* *}$ & $3.116^{* * *}$ & $3.326^{* * *}$ & $3.813^{* * *}$ & $4.266^{* * *}$ \\
\hline $\mathrm{P}$ & $2.745^{* *}$ & $3.132^{* * *}$ & $3.381^{* * *}$ & $3.88^{* * *}$ & $4.329^{* * *}$ \\
\hline \multicolumn{6}{|l|}{ SRI LANKA } \\
\hline $\mathrm{C}$ & $3.036^{* * *}$ & $3.879^{* * *}$ & $4.518^{* * *}$ & $5.076^{* * *}$ & $5.375^{* * *}$ \\
\hline EI & $3.035^{* * *}$ & $3.808^{* * *}$ & $4.389^{* * *}$ & $4.92^{* * *}$ & $5.187^{* * *}$ \\
\hline $\mathrm{F}$ & $2.938^{* *}$ & $3.909^{* * *}$ & $4.562^{* * *}$ & $5.134^{* * *}$ & $5.488^{* * *}$ \\
\hline $\mathrm{P} 1$ & $3.146^{* * *}$ & $3.939^{* * *}$ & $4.553^{* * *}$ & $5.113^{* * *}$ & $5.402^{* * *}$ \\
\hline \multicolumn{6}{|l|}{ SWEDEN } \\
\hline $\mathrm{C}$ & $3.088^{* * *}$ & $4.384^{* * *}$ & $5.822^{* * *}$ & $6.495^{* * *}$ & $6.983^{* * *}$ \\
\hline E & $3.175^{* * *}$ & $4.468^{* * *}$ & $5.942^{* * *}$ & $6.629^{* * *}$ & $7.123^{* * *}$ \\
\hline $\mathrm{F}$ & $2.909^{* *}$ & $4.014^{* * *}$ & $5.331^{* * *}$ & $5.853^{* * *}$ & $6.282^{* * *}$ \\
\hline $\mathrm{P}$ & $3.208^{* * *}$ & $4.454^{* * *}$ & $5.897^{* * *}$ & $6.575^{* * *}$ & $7.096^{* * *}$ \\
\hline \multicolumn{6}{|l|}{ SWITZERLAND } \\
\hline $\mathrm{C}$ & $4.242^{* * *}$ & $4.586^{* * *}$ & $4.947^{* * *}$ & $5.26^{* * *}$ & $5.531^{* * *}$ \\
\hline E & $4.197^{* * *}$ & $4.545^{* * *}$ & $4.931^{* * *}$ & $5.246^{* * *}$ & $5.51^{* * *}$ \\
\hline $\mathrm{F}$ & $4.2^{* * *}$ & $4.539^{* * *}$ & $4.898^{* * *}$ & $5.22^{* * *}$ & $5.485^{* * *}$ \\
\hline $\mathrm{P}$ & $4.225^{* * *}$ & $4.549^{* * *}$ & $4.926^{* * *}$ & $5.223^{* * *}$ & $5.507^{* * *}$ \\
\hline \multicolumn{6}{|l|}{ TAIWAN } \\
\hline $\mathrm{C}$ & $7.169^{* * *}$ & $8.657^{* * *}$ & $10.03^{* * *}$ & $11.083^{* * *}$ & $12.029^{* * *}$ \\
\hline EI & $7.137^{* * *}$ & $8.504^{* * *}$ & $9.872^{* * *}$ & $10.83^{* * *}$ & $11.72^{* * *}$ \\
\hline $\mathrm{F}$ & $7.224^{* * *}$ & $8.704^{* * *}$ & $10.072^{* * *}$ & $11.045^{* * *}$ & $12.049^{* * *}$ \\
\hline $\mathrm{P}$ & $7.409^{* * *}$ & $8.91^{* * *}$ & $10.258^{* * *}$ & $11.268^{* * *}$ & $12.217^{* * *}$ \\
\hline \multicolumn{6}{|l|}{ THAILAND } \\
\hline $\mathrm{C}$ & $3.342^{* * *}$ & $5.989^{* * *}$ & $7.354^{* * *}$ & $8.162^{* * *}$ & $8.794^{* * *}$ \\
\hline E & $3.469^{* * *}$ & $6.06^{* * *}$ & $7.421^{* * *}$ & $8.232^{* * *}$ & $8.893^{* * *}$ \\
\hline $\mathrm{F}$ & $3.552^{* * *}$ & $6.201^{* * *}$ & $7.581^{* * *}$ & $8.419^{* * *}$ & $9.125^{* * *}$ \\
\hline $\mathrm{P}$ & $3.36^{* * *}$ & $6.027^{* * *}$ & $7.465^{* * *}$ & $8.377^{* * *}$ & $9.129^{* * *}$ \\
\hline \multicolumn{6}{|l|}{ TRINIDAD \& TOBAGO } \\
\hline $\mathrm{C}$ & $4.355^{* * *}$ & $4.626^{* * *}$ & $4.55^{* * *}$ & $4.68^{* * *}$ & $5.105^{* * *}$ \\
\hline E & $4.568^{* * *}$ & $5.013^{* * *}$ & $5.066^{* * *}$ & $5.179^{* * *}$ & $5.571^{* * *}$ \\
\hline $\mathrm{F}$ & $4.781^{* * *}$ & $5.266^{* * *}$ & $5.318^{* * *}$ & $5.493^{* * *}$ & $5.924^{* * *}$ \\
\hline $\mathrm{P}$ & $4.593^{* * *}$ & $4.998^{* * *}$ & $4.945^{* * *}$ & $5.184^{* * *}$ & $5.703^{* * *}$ \\
\hline \multicolumn{6}{|l|}{ TUNISIA } \\
\hline $\mathrm{C}$ & 0.734 & $-3.660^{* * *}$ & $-4.166^{* * *}$ & $-2.659^{* *}$ & $-1.792^{*}$ \\
\hline E] & 1.598 & $-3.822^{* * *}$ & $14.806^{* * *}$ & $-2.641^{* *}$ & $-1.800^{*}$ \\
\hline $\mathrm{F}$ & $2.157^{* *}$ & $2.878^{* *}$ & $-4.489^{* * *}$ & $-2.879^{* *}$ & $-1.949^{*}$ \\
\hline $\mathrm{P}$ & 0.977 & $2.457^{* *}$ & $4.554^{* * *}$ & $-3.643^{* * *}$ & $-2.580^{* *}$ \\
\hline \multicolumn{6}{|l|}{ TURKEY } \\
\hline $\mathrm{C}$ & $-2.072^{* *}$ & $-4.575^{* * *}$ & $-5.990^{* * *}$ & $-3.576^{* * *}$ & $-2.250^{* *}$ \\
\hline E & $3.560^{* * *}$ & $-4.150^{* * *}$ & $-5.622^{* * *}$ & $-3.339^{* * *}$ & $-2.135^{* *}$ \\
\hline $\mathrm{F}$ & $7.567^{* * *}$ & $8.603^{* * *}$ & $-6.997^{* * *}$ & $-4.280^{* * *}$ & $-2.781^{* *}$ \\
\hline $\mathrm{Pl}$ & $-3.806^{* * *}$ & $-10.175^{* * *}$ & $-5.048^{* * *}$ & $-2.846^{* *}$ & $-1.749^{*}$ \\
\hline \multicolumn{6}{|l|}{ UAE } \\
\hline $\mathrm{C}$ & $4.26^{* * *}$ & $4.051^{* * *}$ & $3.681^{* * *}$ & $3.469^{* * *}$ & $3.34^{* * *}$ \\
\hline E & $4.497^{* * *}$ & $4.178^{* * *}$ & $3.809^{* * *}$ & $3.566^{* * *}$ & $3.438^{* * *}$ \\
\hline $\mathrm{F}$ & $4.156^{* * *}$ & $3.819^{* * *}$ & $3.475^{* * *}$ & $3.216^{* * *}$ & $3.106^{* * *}$ \\
\hline $\mathrm{P}$ & $4.505^{* * *}$ & $4.214^{* * *}$ & $3.812^{* * *}$ & $3.618^{* * *}$ & $3.51^{* * *}$ \\
\hline UGANDA & & & & & \\
\hline
\end{tabular}




\begin{tabular}{|c|c|c|c|c|c|}
\hline $\mathrm{CR}$ & $3.144^{* * *}$ & $4.532^{* * *}$ & $5.089^{* * *}$ & $5.471^{* * *}$ & $5.787^{* * *}$ \\
\hline ER & $3.305^{* * *}$ & $4.778^{* * *}$ & $5.382^{* * *}$ & $5.766^{* * *}$ & $6.043^{* * *}$ \\
\hline FR & $3.069^{* * *}$ & $4.434^{* * *}$ & $4.956^{* * *}$ & $5.336^{* * *}$ & $5.633^{* * *}$ \\
\hline PR & $3.137^{* * *}$ & $4.497^{* * *}$ & $5.083^{* * *}$ & $5.543^{* * *}$ & $5.768^{* * *}$ \\
\hline \multicolumn{6}{|l|}{ UKRAINE } \\
\hline CR & $3.511^{* * *}$ & $1.832^{*}$ & 1.116 & 0.535 & 0.188 \\
\hline ER & $2.125^{* *}$ & 0.829 & -0.026 & -0.179 & 0.047 \\
\hline FR & $2.397^{* *}$ & 1.055 & 0.085 & -0.376 & -0.631 \\
\hline PR & $4.713^{* * *}$ & $3.007^{* * *}$ & $2.168^{* *}$ & 1.253 & 0.518 \\
\hline \multicolumn{6}{|l|}{ UNITED KINGDOM } \\
\hline CR & $3.771^{* * *}$ & $4.757^{* * *}$ & $5.501^{* * *}$ & $6.018^{* * *}$ & $6.436^{* * *}$ \\
\hline ER & $3.792^{* * *}$ & $4.652^{* * *}$ & $5.429^{* * *}$ & $5.884^{* * *}$ & $6.312^{* * *}$ \\
\hline FR & $3.54^{* * *}$ & $4.363^{* * *}$ & $5.051^{* * *}$ & $5.501^{* * *}$ & $5.893^{* * *}$ \\
\hline PR & $3.6^{* * *}$ & $4.616^{* * *}$ & $5.352^{* * *}$ & $5.856^{* * *}$ & $6.27^{* * *}$ \\
\hline \multicolumn{6}{|l|}{ UNITED STATES } \\
\hline CR & $3.152^{* * *}$ & $4.507^{* * *}$ & $5.214^{* * *}$ & $5.998^{* * *}$ & $6.496^{* * *}$ \\
\hline ER & $3.327^{* * *}$ & $4.696^{* * *}$ & $5.339^{* * * *}$ & $5.993^{* * *}$ & $6.446^{* * *}$ \\
\hline FR & $3.211^{* * *}$ & $4.63^{* * *}$ & $5.276^{* * *}$ & $5.843^{* * *}$ & $6.218^{* * *}$ \\
\hline PR & $3.263^{* * *}$ & $4.695^{* * *}$ & $5.352^{* * *}$ & $6.066^{* * *}$ & $6.465^{* * *}$ \\
\hline \multicolumn{6}{|l|}{ VENEZUELA } \\
\hline CR & $4.11^{* * *}$ & $4.729^{* * *}$ & $5.612^{* * *}$ & $6.576^{* * *}$ & $7.551^{* * *}$ \\
\hline ER & $3.837^{* * *}$ & $4.526^{* * *}$ & $5.412^{* * *}$ & $6.213^{* * *}$ & $7.193^{* * *}$ \\
\hline FR & $3.997^{* * *}$ & $4.642^{* * *}$ & $5.607^{* * *}$ & $6.533^{* * *}$ & $7.634^{* * *}$ \\
\hline PR & $3.798^{* * *}$ & $4.232^{* * *}$ & $4.915^{* * *}$ & $5.64^{* * *}$ & $6.441^{* * *}$ \\
\hline \multicolumn{6}{|l|}{ VIETNAM } \\
\hline $\mathrm{CR}$ & $4.363^{* * *}$ & $5.921^{* * *}$ & $6.804^{* * *}$ & $7.663^{* * *}$ & $8.678^{* * *}$ \\
\hline ER & $4.413^{* * *}$ & $6.085^{* * *}$ & $6.961^{* * *}$ & $7.795^{* * *}$ & $8.843^{* * *}$ \\
\hline FR & $4.42^{* * *}$ & $6.099^{* * *}$ & $7.001^{* * *}$ & $7.846^{* * *}$ & $8.898^{* * *}$ \\
\hline $\begin{array}{l}\text { PR } \\
\end{array}$ & $4.094^{* * *}$ & $5.399^{* * *}$ & $6.163^{* * *}$ & $6.872^{* * *}$ & $7.735^{* * *}$ \\
\hline \multicolumn{6}{|l|}{ ZAMBIA } \\
\hline CR & $4.149^{* * *}$ & $5.196^{* * *}$ & $6.22^{* * *}$ & $6.674^{* * *}$ & $6.999^{* * *}$ \\
\hline ER & $4.481^{* * *}$ & $5.406^{* * *}$ & $6.449^{* * *}$ & $6.894^{* * *}$ & $7.173^{* * *}$ \\
\hline FR & $4.366^{* * *}$ & $5.339^{* * *}$ & $6.35^{* * *}$ & $6.787^{* * *}$ & $7.09^{* * *}$ \\
\hline PR & $4.047^{* * *}$ & $5.027^{* * *}$ & $5.959^{* * *}$ & $6.402^{* * *}$ & $6.609^{* * *}$ \\
\hline \multicolumn{6}{|l|}{ ZIMBABWE } \\
\hline $\mathrm{CR}$ & $-3.741^{* * *}$ & $-2.199^{* *}$ & -0.934 & -0.468 & -0.312 \\
\hline ER & $-1.921^{*}$ & $-1.782^{*}$ & -0.673 & -0.319 & -0.197 \\
\hline FR & $-3.604^{* * *}$ & $-1.706^{*}$ & -0.699 & -0.321 & -0.202 \\
\hline PR & $-2.596^{* *}$ & $-1.895^{*}$ & -0.781 & -0.351 & -0.228 \\
\hline
\end{tabular}

Note: See Notes to Table 2a. $m$ stands for the number of (embedded) dimension which embed the time series into $\mathrm{m}$-dimensional vectors, by taking each $m$ successive points in the series. Value in cell represents BDS z-statistic; ${ }^{*},{ }^{* *}$, and ${ }^{* * *}$ indicates rejection of i.i.d. residuals at 10, 5 and 1 percent level of significance respectively.

Given the strong evidence of nonlinearity in in the relationship between stock returns and country-specific measures of aggregate, economic, financial and political risks, we now turn our attention to the nonparametric $k$-th order test of causality. We can make the following observations from Table 4a: (1) There is evidence of aggregate, economic, financial and political risks in predicting stock returns for 43, 38, 38 and 45 cases at the 5 percent level of significance, which in turn, are many more than picked up under the misspecified linear model; (2) As far as prediction of volatility, as measured by squared returns, is concerned, Chile is the only case for which economic risks show evidence of causality; (3) However, when we look at realized 
volatility based on sum of squared returns of daily data over the number of trading days in a month, there is much stronger evidence of predictability. We find that aggregate and political risks predict realized volatility in 41 countries, economic risks in 34 countries and financial risks in 33 countries. The names of the countries which show predictability for returns, squared returns and realized volatility have been summarized in Table 4b.

Table 4a: Nishiyama et al.,'s (2011) k-th Order Test of Causality

\begin{tabular}{|c|c|c|c|c|}
\hline COUNTRY & $\mathrm{CR}$ & ER & FR & $\mathrm{PR}$ \\
\hline \multicolumn{5}{|l|}{ ARGENTINA } \\
\hline Returns & $27.087^{*}$ & $19.32^{*}$ & $22.919^{*}$ & $27.616^{*}$ \\
\hline Squared returns & 2.784 & 4.525 & 9.550 & 4.004 \\
\hline Realized volatility & 7.706 & 7.555 & 7.006 & 7.496 \\
\hline \multicolumn{5}{|l|}{ AUSTRA } \\
\hline Returns & $53.82^{*}$ & $42.522^{*}$ & $57.483^{*}$ & $53.775^{*}$ \\
\hline Squared returns & 3.546 & 4.410 & 6.310 & 7.753 \\
\hline Realized volatility & $59.11^{*}$ & $47.881^{*}$ & $50.868^{*}$ & $56.251^{*}$ \\
\hline \multicolumn{5}{|l|}{ AUSTRALIA } \\
\hline Returns & $53.864^{*}$ & $39.004^{*}$ & $49.801^{*}$ & $55.552^{*}$ \\
\hline Squared returns & 11.889 & 10.082 & 4.083 & 5.449 \\
\hline Realized volatility & $23.136^{*}$ & $15.387^{*}$ & $20.757^{*}$ & $26.723^{*}$ \\
\hline \multicolumn{5}{|l|}{ BAHRAIN } \\
\hline Returns & $15.695^{*}$ & $14.918^{*}$ & 14.326 & $15.135^{*}$ \\
\hline Squared returns & 6.681 & 4.385 & 4.892 & 6.473 \\
\hline Realized volatility & $40.805^{*}$ & $39.421^{*}$ & $32.63^{*}$ & $40.16^{*}$ \\
\hline \multicolumn{5}{|l|}{ BANGLADESH } \\
\hline Returns & 5.448 & 4.895 & 7.662 & 7.347 \\
\hline Squared returns & 4.190 & 3.851 & 3.042 & 3.575 \\
\hline Realized volatility & 6.483 & 3.027 & 4.759 & 7.689 \\
\hline \multicolumn{5}{|l|}{ BELGIUM } \\
\hline Returns & $54.744^{*}$ & $52.037^{*}$ & $50.335^{*}$ & $52.671^{*}$ \\
\hline Squared returns & 4.517 & 4.888 & 5.929 & 3.506 \\
\hline Realized volatility & $35.297^{*}$ & $35.002^{*}$ & $40.67^{*}$ & $43.93^{*}$ \\
\hline \multicolumn{5}{|l|}{ BOTSWANA } \\
\hline Returns & $21.556^{*}$ & $20.683^{*}$ & 13.965 & $20.953^{*}$ \\
\hline Squared returns & 4.448 & 5.446 & 5.864 & 5.264 \\
\hline Realized volatility & $17.305^{*}$ & $17.365^{*}$ & $27.48^{*}$ & $19.726^{*}$ \\
\hline \multicolumn{5}{|l|}{ BRAZIL } \\
\hline Returns & 3.892 & 2.916 & 2.239 & 3.323 \\
\hline Squared returns & 6.069 & 4.227 & 8.778 & 12.455 \\
\hline Realized volatility & $52.916^{*}$ & $48.869^{*}$ & $50.608^{*}$ & $45.71^{*}$ \\
\hline \multicolumn{5}{|l|}{ BULGARIA } \\
\hline Returns & 0.393 & 0.53 & 0.354 & 0.58 \\
\hline Squared returns & 4.277 & 6.545 & 4.514 & 2.385 \\
\hline Realized volatility & 5.412 & 2.783 & 2.868 & 3.676 \\
\hline \multicolumn{5}{|l|}{ CANADA } \\
\hline Returns & $24.613^{*}$ & $22.503^{*}$ & $24.26^{*}$ & $24.947^{*}$ \\
\hline Squared returns & 2.443 & 4.223 & 1.705 & 1.595 \\
\hline Realized volatility & $39.228^{*}$ & $28.804^{*}$ & $39.112^{*}$ & $34.23^{*}$ \\
\hline \multicolumn{5}{|l|}{ CHILE } \\
\hline Returns & 1.594 & $78.828^{*}$ & 1.307 & 1.52 \\
\hline
\end{tabular}




\begin{tabular}{|c|c|c|c|c|}
\hline Squared returns & 1.838 & $22.045^{*}$ & 7.836 & 7.416 \\
\hline Realized volatility & 13.611 & 12.214 & 12.921 & 13.755 \\
\hline \multicolumn{5}{|l|}{ CHINA } \\
\hline Returns & $18.797^{*}$ & $15.313^{*}$ & $20.741^{*}$ & $17.195^{*}$ \\
\hline Squared returns & 3.352 & 2.711 & 4.733 & 4.460 \\
\hline Realized volatility & $19.043^{*}$ & $19.043^{*}$ & $24.671^{*}$ & $20.261^{*}$ \\
\hline \multicolumn{5}{|l|}{ COLOMBIA } \\
\hline Returns & $18.842^{*}$ & 13.501 & 12.585 & $20.503^{*}$ \\
\hline Squared returns & 5.560 & 7.125 & 5.353 & 4.645 \\
\hline Realized volatility & $16.37^{*}$ & 10.584 & $16.137^{*}$ & $17.794^{*}$ \\
\hline \multicolumn{5}{|l|}{ CROATIA } \\
\hline Returns & 11.43 & $20.08^{*}$ & 13.675 & $29.168^{*}$ \\
\hline Squared returns & 7.641 & 2.854 & 8.337 & 7.583 \\
\hline Realized volatility & 12.238 & 10.055 & 11.62 & 11.382 \\
\hline \multicolumn{5}{|l|}{ CYPRUS } \\
\hline Returns & 11.53 & 11.984 & 11.156 & 11.72 \\
\hline Squared returns & 4.511 & 4.023 & 6.313 & 5.470 \\
\hline Realized volatility & $18.332^{*}$ & $17.294^{*}$ & $17.152^{*}$ & $17.473^{*}$ \\
\hline \multicolumn{5}{|l|}{ CZECH REPUBLIC } \\
\hline Returns & 5.864 & 5.167 & 3.113 & 5.308 \\
\hline Squared returns & 4.747 & 3.311 & 4.519 & 4.596 \\
\hline Realized volatility & 13.446 & 9.574 & 15.787 & 8.868 \\
\hline \multicolumn{5}{|l|}{ DENMARK } \\
\hline Returns & 9.627 & 9.406 & 9.135 & 9.804 \\
\hline Squared returns & 5.666 & 2.890 & 3.532 & 6.750 \\
\hline Realized volatility & 12.99 & 12.7 & 11.899 & 12.521 \\
\hline \multicolumn{5}{|l|}{ EGYPT } \\
\hline Returns & 10.858 & 11.382 & 7.713 & 10.986 \\
\hline Squared returns & 4.093 & 4.744 & 2.715 & 5.309 \\
\hline Realized volatility & 12.649 & 12.45 & 12.823 & $21.858^{*}$ \\
\hline \multicolumn{5}{|l|}{ ESTONIA } \\
\hline Returns & $14.578^{*}$ & $14.669^{*}$ & 13.726 & $14.663^{*}$ \\
\hline Squared returns & 3.413 & 3.793 & 7.651 & 5.528 \\
\hline Realized volatility & 10.531 & 13.139 & 8.686 & 12.433 \\
\hline \multicolumn{5}{|l|}{ FINLAND } \\
\hline Returns & $26.743^{*}$ & $27.271^{*}$ & $22.498^{*}$ & $26.952^{*}$ \\
\hline Squared returns & 5.016 & 6.170 & 4.895 & 5.743 \\
\hline Realized volatility & $41.353^{*}$ & $46.212^{*}$ & $34.429^{*}$ & $42.01^{*}$ \\
\hline \multicolumn{5}{|l|}{ FRANCE } \\
\hline Returns & $16.957^{*}$ & $14.902^{*}$ & $16.497^{*}$ & $14.942^{*}$ \\
\hline Squared returns & 2.457 & 3.535 & 7.418 & 7.337 \\
\hline Realized volatility & 8.577 & 9.059 & 8.259 & 8.756 \\
\hline \multicolumn{5}{|l|}{ GERMANY } \\
\hline Returns & $18.268^{*}$ & $23.116^{*}$ & $24.507^{*}$ & $27.424^{*}$ \\
\hline Squared returns & 5.652 & 4.248 & 4.269 & 4.767 \\
\hline Realized volatility & $42.207^{*}$ & $40.611^{*}$ & $45.461^{*}$ & $44.351^{*}$ \\
\hline \multicolumn{5}{|l|}{ GHANA } \\
\hline Returns & $30.628^{*}$ & $21.811^{*}$ & $26.789^{*}$ & $27.101^{*}$ \\
\hline Squared returns & 3.002 & 1.358 & 5.325 & 2.935 \\
\hline Realized volatility & 1.322 & 0.907 & 1.133 & 1.082 \\
\hline \multicolumn{5}{|l|}{ Greece } \\
\hline Returns & $19.745^{*}$ & $16.603^{*}$ & $15.474^{*}$ & $19.307^{*}$ \\
\hline Squared returns & 3.212 & 3.726 & 5.406 & 4.691 \\
\hline Realized volatility & $20.98^{*}$ & $24.098^{*}$ & $17.577^{*}$ & $20.241^{*}$ \\
\hline
\end{tabular}




\begin{tabular}{|c|c|c|c|c|}
\hline \multicolumn{5}{|l|}{ HONG KONG } \\
\hline Returns & $25.188^{*}$ & $18.756^{*}$ & $23.815^{*}$ & 24.685 \\
\hline Squared returns & 6.063 & 4.012 & 4.923 & 4.969 \\
\hline Realized volatility & $26.346^{*}$ & $25.805^{*}$ & $28.042^{*}$ & $28.707^{*}$ \\
\hline \multicolumn{5}{|l|}{ HUNGARY } \\
\hline Returns & 12.112 & 6.417 & 8.766 & 12.292 \\
\hline Squared returns & 6.674 & 7.619 & 2.966 & 4.612 \\
\hline Realized volatility & 5.476 & 4.106 & 4.71 & 5.558 \\
\hline \multicolumn{5}{|l|}{ ICELAND } \\
\hline Returns & 6.56 & 5.415 & 5.26 & 5.59 \\
\hline Squared returns & 5.174 & 2.990 & 3.858 & 5.595 \\
\hline Realized volatility & 11.866 & 11.184 & 11.7 & 11.285 \\
\hline \multicolumn{5}{|l|}{ INDIA } \\
\hline Returns & $45.519^{*}$ & $39.684^{*}$ & $45.146^{*}$ & $45.18^{*}$ \\
\hline Squared returns & 1.752 & 4.126 & 4.028 & 2.527 \\
\hline Realized volatility & $20.509^{*}$ & $18.13^{*}$ & $21.658^{*}$ & $27.975^{*}$ \\
\hline \multicolumn{5}{|l|}{ INDONESIA } \\
\hline Returns & 0.986 & 0.64 & 1.131 & 0.938 \\
\hline Squared returns & 1.857 & 9.496 & 4.407 & 8.060 \\
\hline Realized volatility & $38.253^{*}$ & $27.558^{*}$ & $36.448^{*}$ & 34.219 \\
\hline \multicolumn{5}{|l|}{ IRELAND } \\
\hline Returns & $41.633^{*}$ & $32.815^{*}$ & $33.563^{*}$ & 33.782 \\
\hline Squared returns & 3.537 & 8.160 & 2.118 & 3.396 \\
\hline Realized volatility & $15.561^{*}$ & $14.653^{*}$ & $15.458^{*}$ & $14.987^{*}$ \\
\hline \multicolumn{5}{|l|}{ ISRAEL } \\
\hline Returns & $23.951^{*}$ & $21.15^{*}$ & $23.327^{*}$ & $23.369^{*}$ \\
\hline Squared returns & 4.680 & 3.399 & 4.809 & 3.504 \\
\hline Realized volatility & $34.549^{*}$ & $24.856^{*}$ & $32.449^{*}$ & $27.84^{*}$ \\
\hline \multicolumn{5}{|l|}{ ITALY } \\
\hline Returns & $17.275^{*}$ & 13.315 & $16.496^{*}$ & $17.722^{*}$ \\
\hline Squared returns & 2.859 & 2.681 & 3.957 & 3.155 \\
\hline Realized volatility & $51.293^{*}$ & $42.445^{*}$ & $52.465^{*}$ & 54.325 \\
\hline \multicolumn{5}{|l|}{ JAMAICA } \\
\hline Returns & 0.932 & 0.586 & 0.707 & 0.854 \\
\hline Squared returns & 9.915 & 6.665 & 2.396 & 3.561 \\
\hline Realized volatility & 8.878 & 5.811 & 8.603 & 9.121 \\
\hline \multicolumn{5}{|l|}{ JAPAN } \\
\hline Returns & $28.274^{*}$ & $24.502^{*}$ & $21.265^{*}$ & $27.941^{*}$ \\
\hline Squared returns & 7.412 & 6.455 & 7.664 & 5.033 \\
\hline Realized volatility & $26.984^{*}$ & $24.479^{*}$ & $25.346^{*}$ & $25.446^{*}$ \\
\hline \multicolumn{5}{|l|}{ JORDAN } \\
\hline Returns & 12.903 & 9.482 & 11.122 & 13.301 \\
\hline Squared returns & 2.132 & 2.319 & 2.682 & 5.665 \\
\hline Realized volatility & 1.199 & 1.226 & 1.285 & 1.622 \\
\hline \multicolumn{5}{|l|}{ KAZAKHSTAN } \\
\hline Returns & 13.125 & 13.387 & $16.291^{*}$ & $14.86^{*}$ \\
\hline Squared returns & 7.865 & 3.348 & 2.744 & 2.459 \\
\hline Realized volatility & 14.089 & 13.744 & $16.478^{*}$ & $17.531^{*}$ \\
\hline \multicolumn{5}{|l|}{ KENYA } \\
\hline Returns & $24.319^{*}$ & $18.842^{*}$ & $21.925^{*}$ & $24.085^{*}$ \\
\hline Squared returns & 3.151 & 6.668 & 3.547 & 4.640 \\
\hline Realized volatility & $16.401^{*}$ & 13.148 & $19.011^{*}$ & $17.488^{*}$ \\
\hline \multicolumn{5}{|l|}{ KUWAIT } \\
\hline Returns & 1.831 & 1.911 & 2.452 & 1.881 \\
\hline
\end{tabular}




\begin{tabular}{|c|c|c|c|c|}
\hline Squared returns & 4.485 & 3.306 & 3.241 & 4.294 \\
\hline Realized volatility & 13.914 & 14.269 & 13.431 & 13.79 \\
\hline \multicolumn{5}{|l|}{ LITHUANIA } \\
\hline Returns & $29.544^{*}$ & $22.316^{*}$ & $21.763^{*}$ & $26.606^{*}$ \\
\hline Squared returns & 2.371 & 3.635 & 2.736 & 4.250 \\
\hline Realized volatility & 1.522 & 1.641 & 1.453 & 1.444 \\
\hline \multicolumn{5}{|l|}{ LUXEMBOURG } \\
\hline Returns & 2.29 & 2.219 & 2.952 & 2.106 \\
\hline Squared returns & 5.139 & 2.052 & 3.440 & 2.965 \\
\hline Realized volatility & 10.122 & 10.137 & 10.96 & 10.622 \\
\hline \multicolumn{5}{|l|}{ MALAYSIA } \\
\hline Returns & $31.851^{*}$ & $28.383^{*}$ & $31.62^{*}$ & $31.59^{*}$ \\
\hline Squared returns & 3.505 & 2.575 & 4.936 & 6.976 \\
\hline Realized volatility & $30.298^{*}$ & $25.979^{*}$ & 33.673 & $26.899^{*}$ \\
\hline \multicolumn{5}{|l|}{ MALTA } \\
\hline Returns & $29.351^{*}$ & $21.056^{*}$ & $19.06^{*}$ & $24.149^{*}$ \\
\hline Squared returns & 3.367 & 5.452 & 4.694 & 4.559 \\
\hline Realized volatility & 3.527 & 1.871 & 4.076 & 2.591 \\
\hline \multicolumn{5}{|l|}{ MEXICO } \\
\hline Returns & 2.684 & 1.522 & 3.134 & 1.304 \\
\hline Squared returns & 6.610 & 3.572 & 6.805 & 2.073 \\
\hline Realized volatility & 4.38 & 3.95 & 4.323 & 4.569 \\
\hline \multicolumn{5}{|l|}{ MOROCCO } \\
\hline Returns & $16.867^{*}$ & 8.229 & 13.027 & $16.93^{*}$ \\
\hline Squared returns & 2.362 & 5.624 & 4.739 & 5.396 \\
\hline Realized volatility & $46.049^{*}$ & $37.295^{*}$ & $35.815^{*}$ & $41.565^{*}$ \\
\hline \multicolumn{5}{|l|}{ NAMIBIA } \\
\hline Returns & $32.588^{*}$ & $36.092^{*}$ & $18.795^{*}$ & $32.16^{*}$ \\
\hline Squared returns & 5.878 & 4.915 & 3.765 & 5.911 \\
\hline Realized volatility & $31.547^{*}$ & $32.573^{*}$ & $27.406^{*}$ & $28.626^{*}$ \\
\hline \multicolumn{5}{|l|}{ NETHERLANDS } \\
\hline Returns & $38.406^{*}$ & $38.107^{*}$ & $35.084^{*}$ & $38.241^{*}$ \\
\hline Squared returns & 5.521 & 6.358 & 3.245 & 3.580 \\
\hline Realized volatility & $22.338^{*}$ & $21.432^{*}$ & $18.203^{*}$ & $25.026^{*}$ \\
\hline \multicolumn{5}{|l|}{ NEW ZEALAND } \\
\hline Returns & $15.197^{*}$ & 11.053 & 13.994 & $15.359^{*}$ \\
\hline Squared returns & 5.956 & 5.621 & 6.631 & 6.811 \\
\hline Realized volatility & 14.172 & 12.955 & 14.329 & 13.224 \\
\hline \multicolumn{5}{|l|}{ NIGERIA } \\
\hline Returns & 3.247 & 3.136 & 2.691 & 2.593 \\
\hline Squared returns & 3.282 & 4.759 & 4.583 & 4.474 \\
\hline Realized volatility & $17.972^{*}$ & $19.018^{*}$ & $17.848^{*}$ & $16.462^{*}$ \\
\hline \multicolumn{5}{|l|}{ NORWAY } \\
\hline Returns & 13.935 & 13.895 & 6.946 & 13.842 \\
\hline Squared returns & 4.178 & 2.023 & 3.315 & 5.560 \\
\hline Realized volatility & $38.038^{*}$ & $31.747^{*}$ & $31.747^{*}$ & $21.356^{*}$ \\
\hline \multicolumn{5}{|l|}{ OMAN } \\
\hline Returns & 2.747 & 2.398 & 2.398 & 2.736 \\
\hline Squared returns & 2.753 & 4.353 & 4.353 & 3.522 \\
\hline Realized volatility & 11.549 & 10.754 & 10.586 & 11.518 \\
\hline \multicolumn{5}{|l|}{ PAKISTAN } \\
\hline Returns & 4.001 & 2.383 & 3.681 & 4.012 \\
\hline Squared returns & 5.983 & 3.742 & 2.132 & 3.321 \\
\hline Realized volatility & 0.157 & 0.062 & 0.077 & 0.558 \\
\hline
\end{tabular}




\begin{tabular}{|c|c|c|c|c|}
\hline \multicolumn{5}{|l|}{ PANAMA } \\
\hline Returns & 8.353 & 6.851 & 6.48 & 5.803 \\
\hline Squared returns & 5.190 & 2.961 & 7.059 & 3.663 \\
\hline Realized volatility & 6.276 & 7.203 & 7.162 & 6.662 \\
\hline \multicolumn{5}{|l|}{ PERU } \\
\hline Returns & 2.896 & 2.806 & 2.959 & 3.107 \\
\hline Squared returns & 4.995 & 3.907 & 5.237 & 7.952 \\
\hline Realized volatility & 3.624 & 3.737 & 3.852 & 3.617 \\
\hline \multicolumn{5}{|l|}{ PHILIPPINES } \\
\hline Returns & $25.525^{*}$ & $20.155^{*}$ & $24.053^{*}$ & $25.667^{*}$ \\
\hline Squared returns & 2.236 & 3.960 & 3.839 & 1.492 \\
\hline Realized volatility & 9.647 & 8.627 & 9.214 & 9.626 \\
\hline \multicolumn{5}{|l|}{ POLAND } \\
\hline Returns & 12.857 & 8.685 & 7.016 & 11.957 \\
\hline Squared returns & 1.982 & 4.783 & 7.130 & 3.721 \\
\hline Realized volatility & 3.093 & 1.615 & 1.832 & 3.026 \\
\hline \multicolumn{5}{|l|}{ PORTUGAL } \\
\hline Returns & 10.446 & 9.712 & 10.116 & 10.213 \\
\hline Squared returns & 8.143 & 6.164 & 3.047 & 4.297 \\
\hline Realized volatility & 1.605 & 1.548 & 1.548 & 1.578 \\
\hline \multicolumn{5}{|l|}{ QATAR } \\
\hline Returns & 2.49 & 4.621 & $38.32^{*}$ & 7.255 \\
\hline Squared returns & 5.232 & 4.790 & 5.639 & 2.654 \\
\hline Realized volatility & 0.21 & 8.049 & 7.835 & 0.176 \\
\hline \multicolumn{5}{|l|}{ ROMANIA } \\
\hline Returns & 3.203 & 2.073 & 2.684 & 3.727 \\
\hline Squared returns & 5.326 & 3.980 & 4.604 & 4.743 \\
\hline Realized volatility & 11.638 & 11.159 & 10.851 & 12.265 \\
\hline \multicolumn{5}{|l|}{ RUSSIA } \\
\hline Returns & $34.207^{*}$ & $31.965^{*}$ & $32.917^{*}$ & $34.25^{*}$ \\
\hline Squared returns & 2.691 & 3.959 & 3.402 & 3.274 \\
\hline Realized volatility & $14.835^{*}$ & 11.489 & 12.803 & 13.582 \\
\hline \multicolumn{5}{|l|}{ SAUDI ARABIA } \\
\hline Returns & 3.263 & 2.303 & 3.25 & 3.159 \\
\hline Squared returns & 5.167 & 3.865 & 4.001 & 3.905 \\
\hline Realized volatility & 9.045 & 7.461 & 9.781 & 10.795 \\
\hline \multicolumn{5}{|l|}{ SINGAPORE } \\
\hline Returns & $20.437^{*}$ & $20.339^{*}$ & $20.057^{*}$ & $20.794^{*}$ \\
\hline Squared returns & 5.892 & 6.723 & 5.253 & 3.022 \\
\hline Realized volatility & 8.145 & 7.154 & 8.269 & 8.282 \\
\hline \multicolumn{5}{|l|}{ SLOVAKIA } \\
\hline Returns & 1.696 & 2.07 & 1.239 & 1.855 \\
\hline Squared returns & 4.027 & 3.540 & 4.598 & 4.739 \\
\hline Realized volatility & $16.073^{*}$ & 9.486 & 10.947 & $80.417^{*}$ \\
\hline \multicolumn{5}{|l|}{ SLOVENIA } \\
\hline Returns & $18.467^{*}$ & 11.306 & $16.285^{*}$ & $18.321^{*}$ \\
\hline Squared returns & 4.515 & 4.922 & 9.141 & 9.870 \\
\hline Realized volatility & $14.547^{*}$ & $14.741^{*}$ & 13.934 & $14.863^{*}$ \\
\hline \multicolumn{5}{|l|}{ SOUTH AFRICA } \\
\hline Returns & $81.498^{*}$ & $58.131^{*}$ & $58.519^{*}$ & $83.344^{*}$ \\
\hline Squared returns & 4.867 & 3.440 & 5.932 & 6.825 \\
\hline Realized volatility & $34.688^{*}$ & $21.179^{*}$ & $29.061^{*}$ & $25.533^{*}$ \\
\hline \multicolumn{5}{|l|}{ SOUTH KOREA } \\
\hline Returns & 78.691* & $75.731^{*}$ & $77.007^{*}$ & $79.241^{*}$ \\
\hline
\end{tabular}




\begin{tabular}{|c|c|c|c|c|}
\hline Squared returns & 1.999 & 2.501 & 6.632 & 4.572 \\
\hline Realized volatility & 0.52 & 0.486 & 0.536 & 0.518 \\
\hline \multicolumn{5}{|l|}{ SPAIN } \\
\hline Returns & 10.708 & 7.888 & 8.005 & 10.357 \\
\hline Squared returns & 3.369 & 5.012 & 4.164 & 2.149 \\
\hline Realized volatility & $30.389^{*}$ & $28.552^{*}$ & $28.266^{*}$ & $30.779^{*}$ \\
\hline \multicolumn{5}{|l|}{ SRI LANKA } \\
\hline Returns & $18.306^{*}$ & 9.212 & $17.7^{*}$ & $18.291^{*}$ \\
\hline Squared returns & 3.245 & 6.677 & 2.703 & 1.761 \\
\hline Realized volatility & $18.642^{*}$ & $17.928^{*}$ & $17.211^{*}$ & $20.939^{*}$ \\
\hline \multicolumn{5}{|l|}{ SWEDEN } \\
\hline Returns & $27.962^{*}$ & $24.631^{*}$ & $26.844^{*}$ & $27.129^{*}$ \\
\hline Squared returns & 4.860 & 1.950 & 6.486 & 3.442 \\
\hline Realized volatility & 0.631 & 0.595 & 0.622 & 0.636 \\
\hline \multicolumn{5}{|l|}{ SWITZERLAND } \\
\hline Returns & 8.384 & 4.746 & 9.109 & 9.885 \\
\hline Squared returns & 3.794 & 3.529 & 10.486 & 1.882 \\
\hline Realized volatility & 3.578 & 2.868 & 2.914 & 3.667 \\
\hline \multicolumn{5}{|l|}{ TAIWAN } \\
\hline Returns & $15.897^{*}$ & 10.776 & $16.89^{*}$ & $17.296^{*}$ \\
\hline Squared returns & 8.359 & 4.662 & 3.983 & 7.585 \\
\hline Realized volatility & $41.396^{*}$ & $39.095^{*}$ & $40.114^{*}$ & $40.104^{*}$ \\
\hline \multicolumn{5}{|l|}{ THAILAND } \\
\hline Returns & 5.152 & 3.719 & 5.295 & 5.192 \\
\hline Squared returns & 6.139 & 5.479 & 4.204 & 7.707 \\
\hline Realized volatility & $18.624^{*}$ & 9.9 & $30.493^{*}$ & $19.686^{*}$ \\
\hline \multicolumn{5}{|c|}{\begin{tabular}{|l|l} 
TRINIDAD \& TOBAGO & \\
\end{tabular}} \\
\hline Returns & $40.596^{*}$ & $40.218^{*}$ & $40.839^{*}$ & $39.48^{*}$ \\
\hline Squared returns & 5.310 & 3.353 & 4.344 & 7.052 \\
\hline Realized volatility & 10.622 & 9.353 & 10.922 & 10.93 \\
\hline \multicolumn{5}{|l|}{ TUNISIA } \\
\hline Returns & $17.371^{*}$ & $14.456^{*}$ & 7.635 & $17.433^{*}$ \\
\hline Squared returns & 4.018 & 2.939 & 3.304 & 4.462 \\
\hline Realized volatility & $51.737^{*}$ & $37.429^{*}$ & $21.39^{*}$ & $53.255^{*}$ \\
\hline \multicolumn{5}{|l|}{ TURKEY } \\
\hline Returns & 5.951 & 4.526 & 5.925 & 5.509 \\
\hline Squared returns & 3.015 & 2.971 & 3.230 & 2.431 \\
\hline Realized volatility & $59.305^{*}$ & $53.541^{*}$ & $51.882^{*}$ & $57.992^{*}$ \\
\hline \multicolumn{5}{|c|}{ The } \\
\hline Returns & 3.666 & 3.707 & 3.846 & 5.158 \\
\hline Squared returns & 4.380 & 3.840 & 3.540 & 3.865 \\
\hline Realized volatility & 11.675 & 8.907 & 11.225 & 11.815 \\
\hline \multicolumn{5}{|l|}{ UGANDA } \\
\hline Returns & 3.89 & 4.22 & 3.785 & 3.757 \\
\hline Squared returns & 4.728 & 3.218 & 6.761 & 3.575 \\
\hline Realized volatility & $20.838^{*}$ & $41.294^{*}$ & 8.368 & $18.852^{*}$ \\
\hline \multicolumn{5}{|l|}{ UKRAINE } \\
\hline Returns & 3.996 & 1.221 & 5.065 & 2.862 \\
\hline Squared returns & 11.853 & 12.824 & 9.202 & 6.759 \\
\hline Realized volatility & 11.007 & 10.357 & 10.599 & 10.9 \\
\hline \multicolumn{5}{|c|}{\begin{tabular}{l|l} 
UNITED KINGDOM &
\end{tabular}} \\
\hline Returns & $20.612^{*}$ & $17.53^{*}$ & $20.552^{*}$ & $20.886^{*}$ \\
\hline Squared returns & 2.124 & 4.516 & 3.764 & 3.186 \\
\hline Realized volatility & $52.34^{*}$ & $28.618^{*}$ & $37.342^{*}$ & $37.635^{*}$ \\
\hline
\end{tabular}




\begin{tabular}{|c|c|c|c|c|}
\hline \multicolumn{5}{|l|}{ UNITED STATES } \\
\hline Returns & $20.675^{*}$ & $20.727^{*}$ & $22.799^{*}$ & $21.434 *$ \\
\hline Squared returns & 4.258 & 4.813 & 4.025 & 3.870 \\
\hline Realized volatility & $49.418^{*}$ & $56.574^{*}$ & $48.035^{*}$ & $49.911^{*}$ \\
\hline \multicolumn{5}{|l|}{ VENEZUELA } \\
\hline Returns & 4.912 & 3.875 & 2.877 & 5.476 \\
\hline Squared returns & 4.366 & 2.903 & 4.500 & 2.020 \\
\hline Realized volatility & $14.543^{*}$ & 13.741 & 12.618 & 13.407 \\
\hline \multicolumn{5}{|l|}{ VIETNAM } \\
\hline Returns & 0.722 & 1.693 & 1.18 & 1.463 \\
\hline Squared returns & 3.356 & 7.103 & 5.705 & 3.258 \\
\hline Realized volatility & 0.126 & 0.094 & 0.081 & 0.22 \\
\hline \multicolumn{5}{|l|}{ ZAMBIA } \\
\hline Returns & $19.809^{*}$ & $18.286^{*}$ & $22.088^{*}$ & $18.387^{*}$ \\
\hline Squared returns & 4.594 & 5.759 & 3.537 & 2.600 \\
\hline Realized volatility & 10.953 & 8.329 & 8.338 & 8.553 \\
\hline \multicolumn{5}{|l|}{ ZIMBABWE } \\
\hline Returns & 1.139 & 3.998 & 2.823 & 0.696 \\
\hline Squared returns & 3.296 & 3.389 & 2.728 & 4.309 \\
\hline Realized volatility & 6.945 & 5.521 & 5.982 & 4.801 \\
\hline
\end{tabular}

Note: See Notes to Table 2a; * represents rejection of the null of non-causality due to risk measures on stock returns, squared returns and realized volatility at the $5 \%$ level of significance, which has a critical value of 14.380 .

Table 4b: Summary of the Nishiyama et al., (2011) test:

\begin{tabular}{|c|c|c|c|c|}
\hline & CR & ER & FR & PR \\
\hline \multirow[t]{30}{*}{ Returns } & Argentina & Argentina & Argentina & Argentina \\
\hline & Australia & Australia & Australia & Australia \\
\hline & Austria & Austria & Austria & Austria \\
\hline & Bahrain & Bahrain & Belgium & Bahrain \\
\hline & Belgium & Belgium & Canada & Belgium \\
\hline & Botswana & Botswana & China & Botswana \\
\hline & Canada & Canada & Finland & Canada \\
\hline & China & Chile & France & China \\
\hline & Colombia & China & Germany & Colombia \\
\hline & Estonia & Croatia & Ghana & Croatia \\
\hline & Finland & Estonia & Greece & Estonia \\
\hline & France & Finland & Hong Kong & Finland \\
\hline & Germany & France & India & France \\
\hline & Ghana & Germany & Israel & Germany \\
\hline & Greece & Ghana & Ireland & Ghana \\
\hline & Hong Kong & Greece & Italy & Greece \\
\hline & India & Hong Kong & Japan & Hong Kong \\
\hline & Israel & India & Kazakhstan & India \\
\hline & Ireland & Israel & Kenya & Israel \\
\hline & Italy & Ireland & Lithuania & Ireland \\
\hline & Japan & Japan & Malaysia & Italy \\
\hline & Kenya & Kenya & Malta & Japan \\
\hline & Lithuania & Lithuania & Namibia & Kazakhstan \\
\hline & Malaysia & Malaysia & Netherlands & Kenya \\
\hline & Malta & Malta & Philippines & Lithuania \\
\hline & Morocco & Namibia & Qatar & Malaysia \\
\hline & Namibia & Netherlands & Russia & Malta \\
\hline & Netherlands & Philippines & Singapore & Morocco \\
\hline & New Zealand & Russia & Slovenia & Namibia \\
\hline & Philippines & Singapore & South Africa & Netherlands \\
\hline
\end{tabular}




\begin{tabular}{|c|c|c|c|c|}
\hline & $\begin{array}{l}\text { Russia } \\
\text { Singapore } \\
\text { Slovenia } \\
\text { South Africa } \\
\text { South Korea } \\
\text { Sri Lanka } \\
\text { Sweden } \\
\text { Taiwan } \\
\text { Trinidad \& Tobago } \\
\text { Tunisia } \\
\text { United Kingdom } \\
\text { United States } \\
\text { Zambia }\end{array}$ & $\begin{array}{l}\text { South Africa } \\
\text { South Korea } \\
\text { Sweden } \\
\text { Trinidad \& Tobago } \\
\text { Tunisia } \\
\text { United Kingdom } \\
\text { United States } \\
\text { Zambia }\end{array}$ & $\begin{array}{l}\text { South Korea } \\
\text { Sri Lanka } \\
\text { Sweden } \\
\text { Taiwan } \\
\text { Trinidad \& Tobago } \\
\text { United Kingdom } \\
\text { United States } \\
\text { Zambia }\end{array}$ & $\begin{array}{l}\text { New Zealand } \\
\text { Philippines } \\
\text { Russia } \\
\text { Singapore } \\
\text { Slovenia } \\
\text { South Africa } \\
\text { South Korea } \\
\text { Sri Lanka } \\
\text { Sweden } \\
\text { Taiwan } \\
\text { Trinidad \& Tobago } \\
\text { Tunisia } \\
\text { United Kingdom } \\
\text { United States } \\
\text { Zambia }\end{array}$ \\
\hline Squared returns & & Chile & & \\
\hline Realized volatility & $\begin{array}{l}\text { Australia } \\
\text { Austria } \\
\text { Bahrain } \\
\text { Belgium } \\
\text { Botswana } \\
\text { Brazil } \\
\text { Canada } \\
\text { China } \\
\text { Colombia } \\
\text { Cyprus } \\
\text { Finland } \\
\text { Germany } \\
\text { Greece } \\
\text { Hong Kong } \\
\text { India } \\
\text { Indonesia } \\
\text { Israel } \\
\text { Ireland } \\
\text { Italy } \\
\text { Japan } \\
\text { Kenya } \\
\text { Malaysia } \\
\text { Morocco } \\
\text { Namibia } \\
\text { Netherlands } \\
\text { Nigeria } \\
\text { Norway } \\
\text { Russia } \\
\text { Slovakia } \\
\text { Slovenia } \\
\text { South Africa } \\
\text { Spain } \\
\text { Sri Lanka } \\
\text { Taiwan } \\
\text { Thailand } \\
\text { Tunisia } \\
\text { Turkey } \\
\text { Uganda } \\
\text { United Kingdom } \\
\text { United States } \\
\text { Venezuela }\end{array}$ & $\begin{array}{l}\text { Australia } \\
\text { Austria } \\
\text { Bahrain } \\
\text { Belgium } \\
\text { Botswana } \\
\text { Brazil } \\
\text { Canada } \\
\text { China } \\
\text { Cyprus } \\
\text { Finland } \\
\text { Germany } \\
\text { Greece } \\
\text { Hong Kong } \\
\text { India } \\
\text { Indonesia } \\
\text { Israel } \\
\text { Ireland } \\
\text { Italy } \\
\text { Japan } \\
\text { Malaysia } \\
\text { Morocco } \\
\text { Namibia } \\
\text { Netherlands } \\
\text { Nigeria } \\
\text { Norway } \\
\text { Slovenia } \\
\text { South Africa } \\
\text { Spain } \\
\text { Sri Lanka } \\
\text { Taiwan } \\
\text { Turkey } \\
\text { Uganda } \\
\text { United Kingdom } \\
\text { United States }\end{array}$ & $\begin{array}{l}\text { Australia } \\
\text { Austria } \\
\text { Bahrain } \\
\text { Belgium } \\
\text { Botswana } \\
\text { Brazil } \\
\text { Canada } \\
\text { China } \\
\text { Colombia } \\
\text { Cyprus } \\
\text { Finland } \\
\text { Germany } \\
\text { Greece } \\
\text { Hong Kong } \\
\text { India } \\
\text { Indonesia } \\
\text { Israel } \\
\text { Ireland } \\
\text { Italy } \\
\text { Japan } \\
\text { Kenya } \\
\text { Morocco } \\
\text { Namibia } \\
\text { Netherlands } \\
\text { Nigeria } \\
\text { Norway } \\
\text { South Africa } \\
\text { Spain } \\
\text { Taiwan } \\
\text { Tunisia } \\
\text { Turkey } \\
\text { United Kingdom } \\
\text { United States }\end{array}$ & $\begin{array}{l}\text { Australia } \\
\text { Austria } \\
\text { Bahrain } \\
\text { Belgium } \\
\text { Botswana } \\
\text { Brazil } \\
\text { Canada } \\
\text { China } \\
\text { Colombia } \\
\text { Cyprus } \\
\text { Egypt } \\
\text { Finland } \\
\text { Germany } \\
\text { Greece } \\
\text { Hong Kong } \\
\text { India } \\
\text { Indonesia } \\
\text { Israel } \\
\text { Ireland } \\
\text { Italy } \\
\text { Japan } \\
\text { Kazakhstan } \\
\text { Kenya } \\
\text { Malaysia } \\
\text { Morocco } \\
\text { Namibia } \\
\text { Netherlands } \\
\text { Nigeria } \\
\text { Norway } \\
\text { Slovakia } \\
\text { Slovenia } \\
\text { South Africa } \\
\text { Spain } \\
\text { Sri Lanka } \\
\text { Taiwan } \\
\text { Thailand } \\
\text { Tunisia } \\
\text { Turkey } \\
\text { Uganda } \\
\text { United Kingdom } \\
\text { United States }\end{array}$ \\
\hline
\end{tabular}

Note: See Notes to Table 2a. 
In sum, our results indicate that while aggregate risk and its various components is a quite strong predictor of returns and realized volatility, when we allow for nonlinearity. From a general perspective, we highlight the importance of accounting for possible misspecifications in a linear model, which in turn, might lead to erroneous inferences.

\section{Conclusions}

There exists a literature which has shown that country risks affect stock market returns and volatility. Against this backdrop, the objective of this paper is to analyze the role played by aggregate risks, as well as its components, namely economic, financial and political, in predicting movements in stock returns and volatility of 83 developed and developing economies. For our purpose, we use the $k$-th order nonparametric causality test of Nishiyama et al., (2011) at monthly frequency over the period of 1984:1 to 2015:12. This test is developed to incorporate higher-order interrelationships inherently based on a nonlinear dependence structure between the investigated variables in question. Besides squared returns to capture volatility, we also use measure of realized volatility, given that we have daily data on the stock prices of these countries. Our decision to use a k-th order nonparametric approach, besides allowing us to for higherorder predictability, controls for the misspecification of a linear framework of causality, which as we show does exist in the relationship between stocks returns and the various measues of country risks. Hence, the weak evidence of causality obtained under the linear Granger tests cannot be relied upon. When we apply the nonparametric test, we find that, while there is no evidence of predictability of squared stock returns except for Chile, at times, there are nearly 50 percent of the cases where the aggregate risks and its components tend to predict stock returns and realized volatility. Hence, our results highlight the importance of modelling nonlinearity in causal relationships between the stock markets and credit risks to avoid drawing incorrect conclusions. As part of future research, given that the stock returns depict skewed distributions, one could apply nonparametric quantiles-based test of causality as in Balcilar et al., (2016), which has an advantage over the conditional-mean based test of Nishiyama et al., (2011), in the sense that the causality-in-quantiles method covers the entire conditional distribution of stock returns and volatility. In addition, it would be interesting to see if our results hold over an out-of-sample period, since in-sample predictability (as conducted here), does not necessarily guarantee forecasting gains (Rapach and Zhou, 2013). 


\section{References}

Andersen, T. G., \& Bollerslev, T. (1998). Answering the skeptics: Yes, standard volatility models do provide accurate forecasts. International economic review, 885-905.

Aye, G. C., Balcilar, M., \& Gupta, R. (2015). International stock return predictability: Is the role of US time-varying? Empirica, DOI: 10.1007/s10663-015-9313-3.

Balcilar, M., Bekiros, S., and Gupta, R. (2016). The role of news-based uncertainty indices in predicting oil markets: a hybrid nonparametric quantile causality method. Empirical Economics, DOI: 10.1007/s00181-016-1150-0.

Bekiros, S., Gupta, R., and Kyei, C. (2016a). On economic uncertainty, stock market predictability and nonlinear spillover effects. North American Journal of Economics and Finance, 36, 184-191.

Bekiros, S., Gupta, R., and Majumdar, A. (2016b). Incorporating Economic Policy Uncertainty in US Equity Premium Models: A Nonlinear Predictability Analysis. Finance Research Letters, 18(1), 291-296.

Bilson, C. M., Brailsford, T. J., \& Hooper, V. C. (2002). The explanatory power of political risk in emerging markets. International Review of Financial Analysis, 11(1), 1-27.

Brock, W., Dechert, D., Scheinkman, J., and LeBaron, B. (1996). A test for independence based on the correlation dimension. Econometric Reviews, 15 197-235.

Cermeño, R., \& Suleman, M. T. (2014). Country Risk and Volatility of Stock Returns: PanelGARCH Evidence for Latin America. Available at SSRN 2482038.

Diamonte, R. L., Liew, J. M., \& Stevens, R. L. (1996). Political risk in emerging and developed markets. Financial Analysts Journal, 52(3), 71-76.

Erb, C. B., Harvey, C. R., \& Viskanta, T. E. (1996). Political risk, economic risk, and financial risk. Financial Analysts Journal, 52(6), 29-46.

Erb, C. B., Harvey, C. R., \& Viskanta, T. E. (1995). Country risk and global equity selection. The Journal of Portfolio Management, 21(2), 74-83.

Hassan, M. K., Maroney, N. C., El-Sady, H. M., \& Telfah, A. (2003). Country risk and stock market volatility, predictability, and diversification in the Middle East and Africa. Economic Systems, 27(1), 63-82.

Nishiyama, Y., Hitomi, K., Kawasaki, Y., and Jeong, K., (2011). A consistent nonparametric Test for nonlinear causality - specification in time series regression. Journal of Econometrics 165, 112-127.

Poon, S-H, and Granger, C. W. J. (2003). Forecasting Volatility in Financial Markets: A Review. Journal of Economic Literature, 41(2), 478-539. 
Ramcharran, H. (2003). Estimating the impact of risks on emerging equity market performance: Further evidence on data from rating agencies.Multinational Business Review, 11(3), 77-90.

Rapach, D. E., Wohar, M. E., and Rangvid, J. (2005). Macro Variables and International Stock Return Predictability. International Journal of Forecasting, 21(1), 137-166.

Rapach, D. E., Wohar, M. E., and Strauss, J. (2008). Forecasting Stock Return Volatility in the Presence of Structural Breaks, in Forecasting in the Presence of Structural Breaks and Model Uncertainty, David E. Rapach and Mark E. Wohar (Eds.), Vol. 3 of Frontiers of Economics and Globalization, Bingley, United Kingdom: Emerald, 381-416.

Rapach, D. E., and Zhou, G. (2013). Forecasting stock returns. Handbook of Economic Forecasting, 2(Part A), Graham Elliott and Allan Timmermann (Eds.), Amsterdam: Elsevier, 328-383.

Suleman, M. T., and Daglish, T. C. (2015). Political Uncertainty in Developed and Emerging Markets. Available at SSRN 2647888.

Suleman, M. T and Randal, J. (2016). Dynamics of Political Risk Rating and Stock Market Volatility. Available at SSRN 2315645. 